\title{
Characterization of Seafood Proteins Causing Allergic Diseases
}

\author{
Anas M. Abdel Rahman', Robert J. Helleur², \\ Mohamed F. Jeebhay ${ }^{3}$ and Andreas L. Lopata ${ }^{4}$ \\ ${ }^{1}$ Samuel Lunenfeld Research Institute, Mount Sinai Hospital, Toronto, ON, \\ ${ }^{2}$ Department of Chemistry, Memorial University of Newfoundland, St. John's, NL \\ ${ }^{3}$ Centre for Occupational and Environmental Health Research, University of Cape Town \\ ${ }^{4}$ School of Pharmacy and Molecular Science, James Cook University \\ 1,2Canada \\ ${ }^{3}$ South Africa \\ ${ }^{4}$ Australia
}

\section{Introduction}

Food allergy is increasing at a faster rate than any other allergic disorder (Gupta et al., 2007). In the last few decades, a large movement toward healthier eating makes seafood one of the major foods consumed worldwide (Wild \& Lehrer, 2005). Consequently, the international trade of seafood has been growing rapidly, which reflects the popularity and frequency of consumption worldwide. The United States has become the third largest consumer of seafood in the world, with 1.86 billion $\mathrm{kg}$ of crustaceans in 2007 (6.04 kg/capita/year)(Food and Agriculture Organisation, 2007). Since seafood ingestion can cause severe acute hypersensitivity reactions and is recognized as one of the most common food allergies, the increased production and consumption of seafood has resulted in more frequent health problems (Lopata \& Lehrer, 2009; Lopata et al., 2010). Exposure to seafood can cause a variety of health problems, including gastrointestinal disorders, urticaria, immunoglobulin E (IgE)-mediated asthma and anaphylaxis (Bang et al., 2005; Lopata \& Lehrer, 2009; Malo \& Cartier, 1993; Sicherer et al., 2004; Wild \& Lehrer, 2005).

A true allergy is known as type-one hypersensitivity that activates the human mast cells, a type of white blood cells, producing an IgE response as seen in Fig. 1. This activation releases histamine and other inflammatory mediators such as cytokines. These immunological activities result in different allergenic symptoms such as itchiness, dyspnea, and anaphylaxis. High-molecular mass proteins seem to be the cause of chronic dermatitis (Greenberg et al., 2003).

Allergic reactions are directed to two major groups: fish and shellfish. Shellfish includes crustaceans and mollusks. Fish is subdivided into bony fish and cartilaginous fish (sharks and rays), whereas most edible species belong to bony fish such as cod and carp (see Table1) (Lopata \& Lehrer, 2009). 


\begin{tabular}{|c|c|c|}
\hline Phylum & Class & Family species (common name) \\
\hline Arthropoda & Gastropoda & $\begin{array}{l}\text { Crabs, lobsters, prawns, } \\
\text { shrimp, scampi, shrimpmeal }\end{array}$ \\
\hline Mollusca & $\begin{array}{l}\text { Gastropoda } \\
\text { Bivalvia }\end{array}$ & $\begin{array}{l}\text { Ablone } \\
\text { Clams, oysters, mussels, } \\
\text { scallops }\end{array}$ \\
\hline & Cephalopoda & $\begin{array}{l}\text { Cuttlefish (and bone), octopus, } \\
\text { squid }\end{array}$ \\
\hline Pisces (sub-phylum Chordata) & Osteichthyes (bony fish) & $\begin{array}{l}\text { Salmon, plaice, tuna, hake, cod, } \\
\text { herring, pilchard, anchovy, } \\
\text { trout, swordfish, sole, pomfret, } \\
\text { yellowfin, fishmeal (flour) }\end{array}$ \\
\hline & $\begin{array}{l}\text { Chondrichthyes } \\
\text { (Cartilaginous fish) }\end{array}$ & shark (cartilage) \\
\hline $\begin{array}{l}\text { Other non-seafood associated } \\
\text { biological agents }\end{array}$ & & $\begin{array}{l}\text { Hoya (sea-squirt), Anisakis, } \\
\text { Red soft coral, Daphnia, Marine } \\
\text { sponge, Algae }\end{array}$ \\
\hline
\end{tabular}

Table 1. Seafood species causing occupational allergy and asthma [Reproduced with permission from (Jeebhay et al., 2001)].

\subsection{Shellfish allergens}

In shellfish, crustaceans and mollusks, the protein tropomyosin (TM) seems to be the major allergen responsible for ingestion-related allergic reactions (Table1). Tropomyosin belongs to the family of actin filament-binding proteins with different isoforms that can be expressed in muscle, and non-muscle tissues. A complex of TM and troponin regulates the calcium sensitive interaction of actin and myosin. Tropomyosin in crustaceans was first identified in shrimp in 1981 by Hoffman et al (Hoffman et al., 1981). Shanti et al. reported an $86 \%$ amino acid sequence homology between the Penaeus indicus shrimp allergen Pen i 1 and fruit fly (Drosophila melanogaster) TM (Shanti et al., 1993). The open reading frame of the cloned TM in invertebrates was reported to be 281-amino acids with a monomeric molecular weight ranging from 38-41 $\mathrm{kDa}$. The highly conserved amino acid sequence of TM is responsible for its identification as a panallergen for cross-reactivity between crustaceans, insects, arachnids, and different classes of mollusks (Rodriguez et al., 1997; Wild \& Lehrer, 2005). In addition, the allergenicity of TM was confirmed in six species of crustaceans: black tiger prawn, kuruma prawn, pink shrimp, king crab, snow crab, and horsehair crab by immunoblotting and the overall sequence identity showed more than $90 \%$ homology (Motoyama et al., 2007).

Many other allergens have been identified in crustaceans. Yu's group identified arginine kinase (AK) (40 kDa) as a novel shrimp allergen (Yu et al., 2003). The amino acid sequence of 


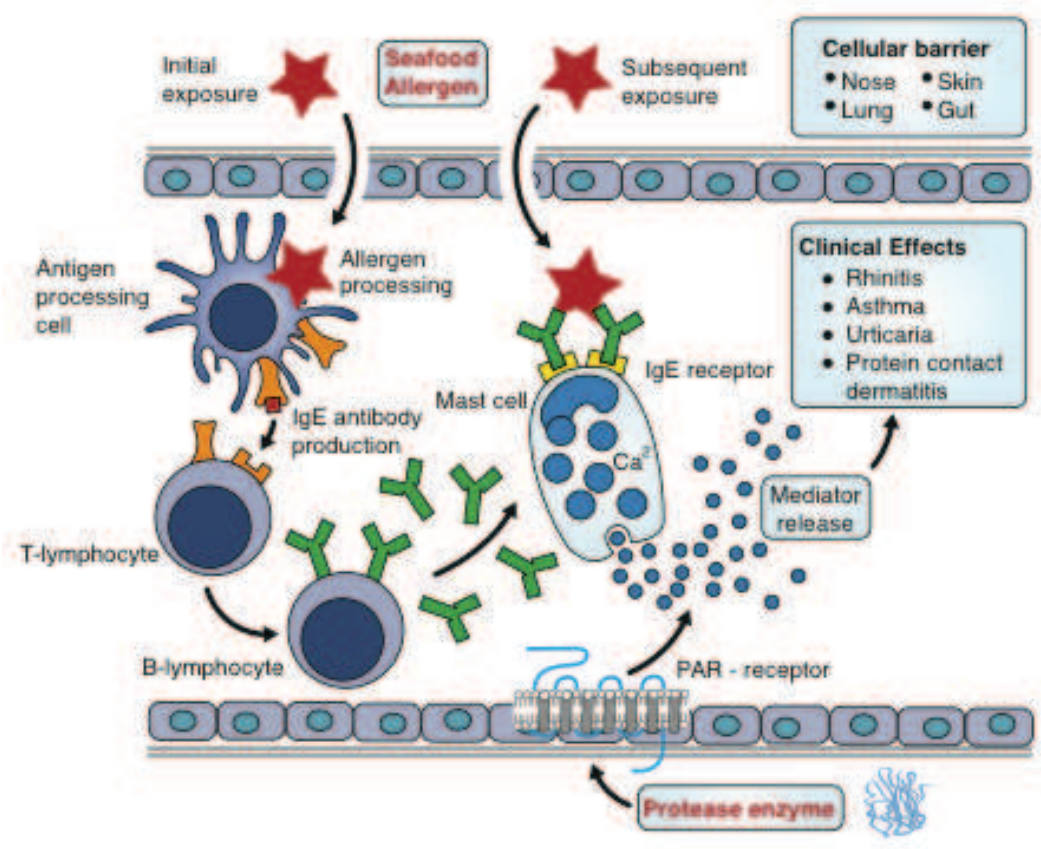

Fig. 1. Mechanisms of allergic and non-allergic inflammation in seafood exposed individuals (Modified and adapted from (Lehrer et al., 1996).

this protein showed $60 \%$ similarity to AK of the crustacean, kuruma prawn (Penaeus japonicas) (Yu et al., 2003). AK was recently reported as an allergen in different crustacean species which was identified in white shrimp (Litopenaeus vannamei) (García-Orozco et al., 2007), gulf shrimp (Penaeus aztecus) (France et al., 1997), chinese shrimp (Fenneropenaeus chinensis) (Yao et al., 2005), black tiger prawn (Penaeus monodon) and other shrimp species using a proteomics approach (Abdel Rahman et al., 2010a; Yu et al., 2003). Moreover, AK has been identified in other crab species: mud crab (Scylla serrata) (Shen et al., 2011), and by our group in snow crab (Chionoecetes opilio) (Abdel Rahman et al., 2011), where 49\% of the participant patient's sera have a reactivity with AK. Arginine kinase also has been reported is allergen in some other invertebrates, such as the house dust mite (Dermatophagoides farinae) (Bi \& Chew, 2004), Indian-meal moth (Plodia interpunctella) (Binder et al., 2001), and silkworm larvae (Bombyx mori) (Liu et al., 2009).

Recent studies have reported other novel crustacean allergens. In 2008, Shiomi et al. identified the immunoreactive band (20 kDa) as sarcoplasmic reticulum Ca-binding protein, which was consequently extracted from black tiger shrimp (Penaeus monodon) (Shiomi et al., 2008). Recently, this allergen was also identified in white shrimp (Litopenaeus vannamei) (Ayuso et al., 2009), and in snow crab (Chionoecetes opilio) (Abdel Rahman et al., 2011). Sarcoplasmic calcium binding protein $(\mathrm{SCP})$ is an invertebrate EF-hand calcium buffering protein that fulfills a similar function in muscle relaxation as vertebrate major allergen parvalbumin (White et al., 2011).

In 2008, myosin light chain was identified as an allergen in white shrimp (Litopenaeus vannamei) (Ayuso et al., 2008; 2010), and our group also identified in black tiger prawn (Penaeus 
monodon) (Abdel Rahman et al., 2010a). Since TM is a common allergen in both crustaceans and mollusks (Ishikawa et al., 1998a;b; Lopata et al., 1997; Miyazawa et al., 1996; Suma et al., 2007), other potent allergens such as myosin heavy chain (Martins et al., 2004), troponin, actine, hemocyanin (Juji et al., 1990; Koshte et al., 1989; Maeda et al., 1991), and amylase (Azofra \& Lombardero, 2003) are reported also in molluscan shellfish. These allergens were identified and characterized in different species such as mussel, oyster, and could exist alone in crustaceans (Table 2) (Taylor, 2008). Some of these allergenic proteins are rapidly degraded within a short period of digestion time, while TM seems to be relatively resistant to acidic digestion (Huang et al., 2010; Liu et al., 2010; 2011).

\subsection{Fish allergens}

The Atlantic cod was the first model for studying fish allergens, Gad c 1(12 kDa) (Aas \& Elsayed, 1969; Aas \& Lundkvist, 1973; Elsayed \& Aas, 1970). This glycoprotein is identified later as parvalbumin, which buffers calcium during muscle relaxation. Parvalbumin has a higher natural abundance in the lower invertebrates than the fast twitch muscles of higher vertebrates (Lehky et al., 1974). Parvalbumin represents the major clinical cross-reactive fish allergen with sequence homology ranging from $60-80 \%$. This feature was comprehensively applied to exploit the closeness between fish allergens and their human homologs (Jenkins et al., 2007). Parvalbumin, with allergen molecular mass ranges from 10-13 kDa, contains heat-resistant linear epitopes that are stabilized by the interaction of metal-binding domains (Lopata \& Lehrer, 2009). The allergenicity of the parvalbumin was studied in purified forms from different types of fish along with two other high molecular weight allergens: 29 and 54 kDa (Beale et al., 2009; Lim et al., 2008; Rehbein \& Lopata, 2011). The polymeric form of the parvalbumin is also reported as a high molecular weight allergen (Besler et al., 2000; Rosmilah et al., 2005). In addition, other fish allergens are characterized such as collagen and gelatin isolated from skin (Sakaguchi et al., 2000) and muscle tissues (Taylor et al., 2004), fish hormones like vitellogenin in caviar (Escudero et al., 2007; Perez-Gordo et al., 2008), and many other allergens reviewed in detail by Lopata and Lehrer 2009. The literature reports that there is no cross-reactivity between fish allergens and shellfish (Lopata \& Lehrer, 2009).

\section{Allergen discovery platforms}

Raw and cooked seafood extracts are used to diagnose allergic sensitization in individuals by skin prick test (Jeebhay et al., 2008). These in-vivo assays lack the molecular information needed for component resolved diagnostics and initiated the development of various biomolecular and chemical approaches.

The seafood allergens discovery platform is reviewed as described in Fig. 2, which starts with the allergenic protein separation, western blotting, and amino acid sequencing. This developed strategy for allergen identification has expedited the discovery of the seafood allergens in two dimensions: among the same species (different allergens) and between other species (cross-reactivity). The cross-reactivity between the novel allergen and the equivalent protein in other species can be investigated by applying the same strategy that is used for the investigation but using the same antibody. The idea for this strategy is based mainly on the high level of homology between the same functional proteins, which makes the extensive characterization using molecular biology techniques more feasible. The most common seafood allergens and the used method(s) for the characterization and quantification are summarized in Table 2. 


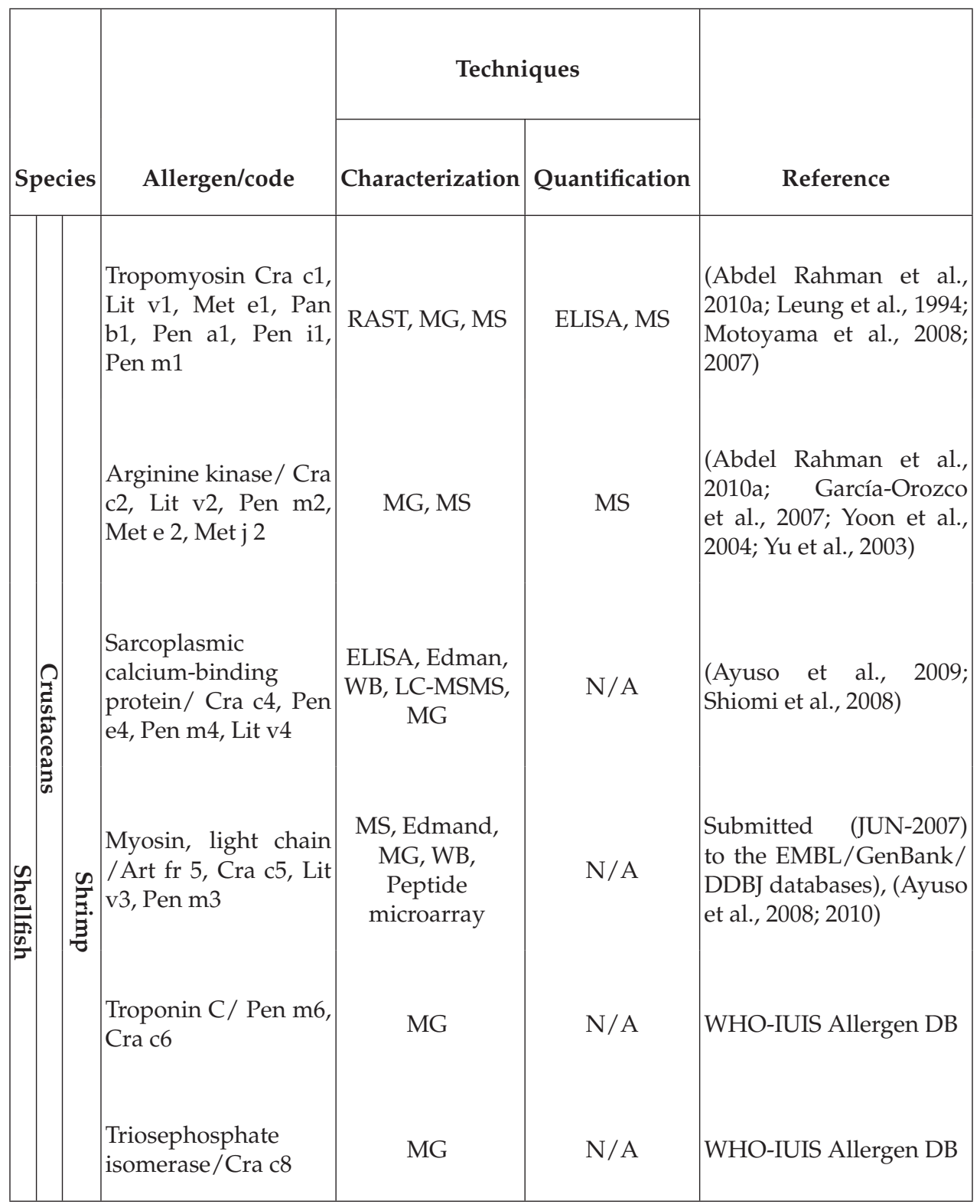

Table 2. The most common known seafood allergens and the method of their characterization and quantification. [MG: Molecular genetics, WB: western blotting, MS: Mass spectrometry, ELISA: Enzyme-linked immunosorbent assay] 


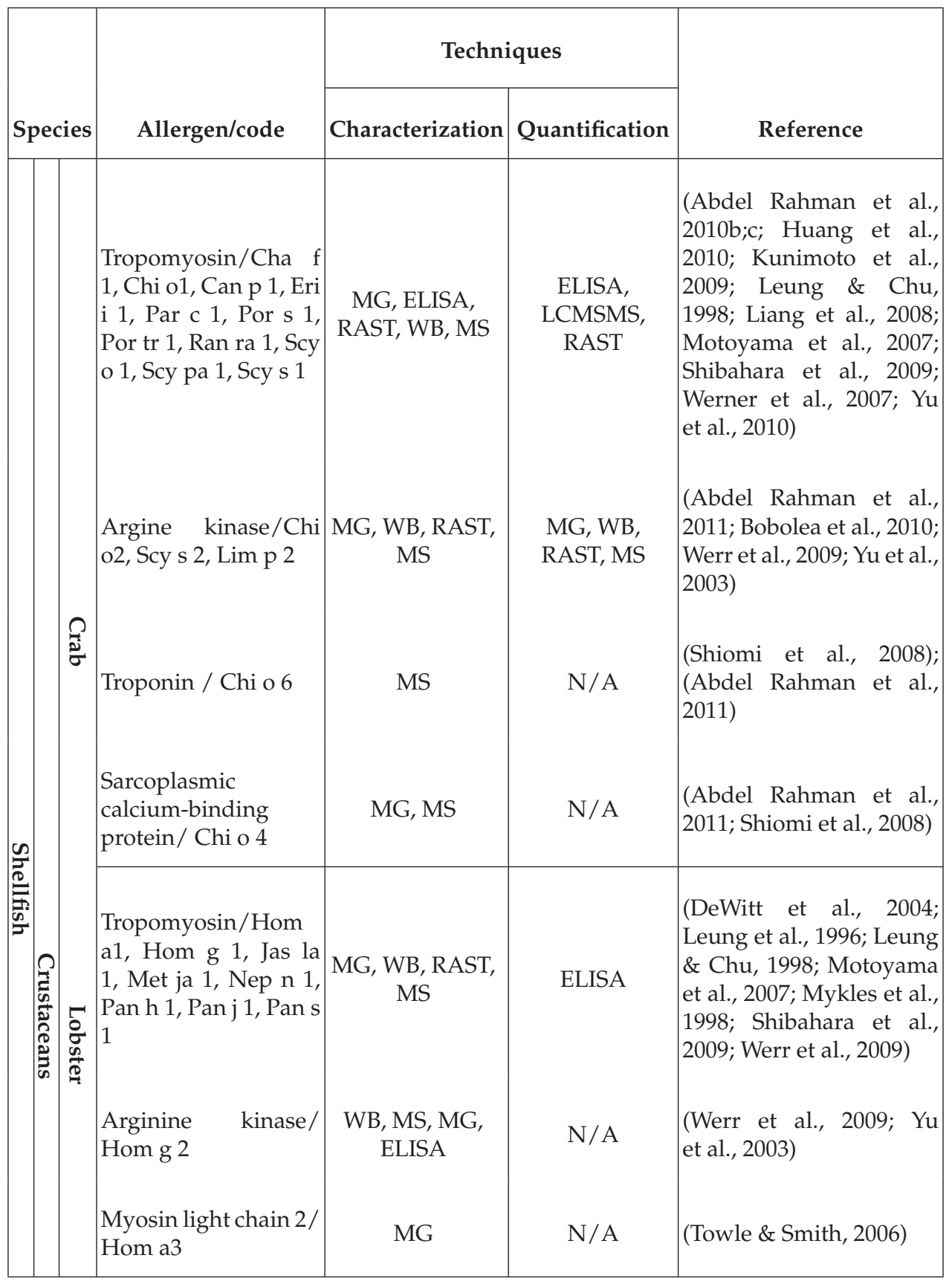

Table 2. The most common known seafood allergens continued from previous page 


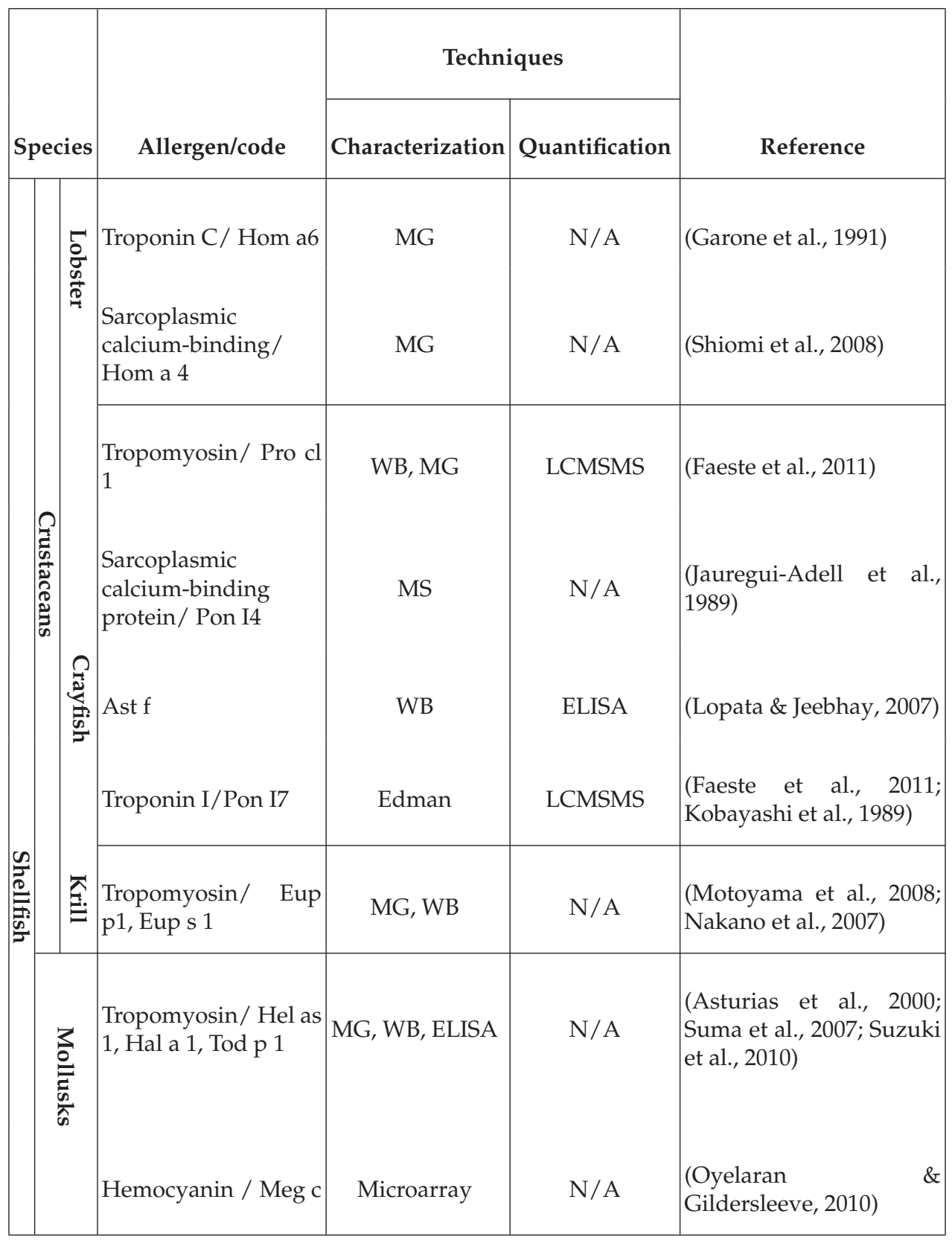

Table 2. The most common known seafood allergens ..... continued from previous page 


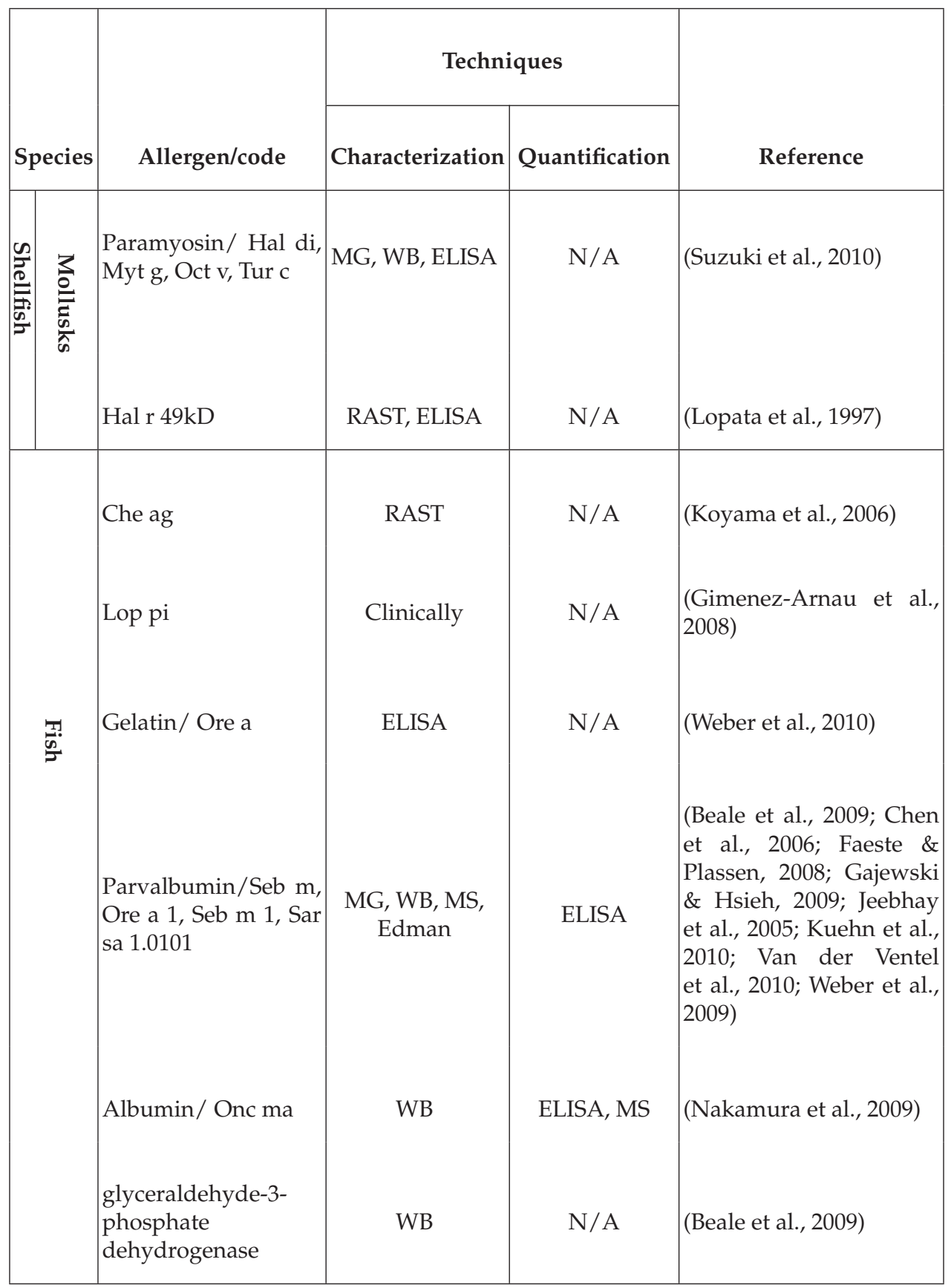

Table 2. The most common known seafood allergens ..... continued from previous page 


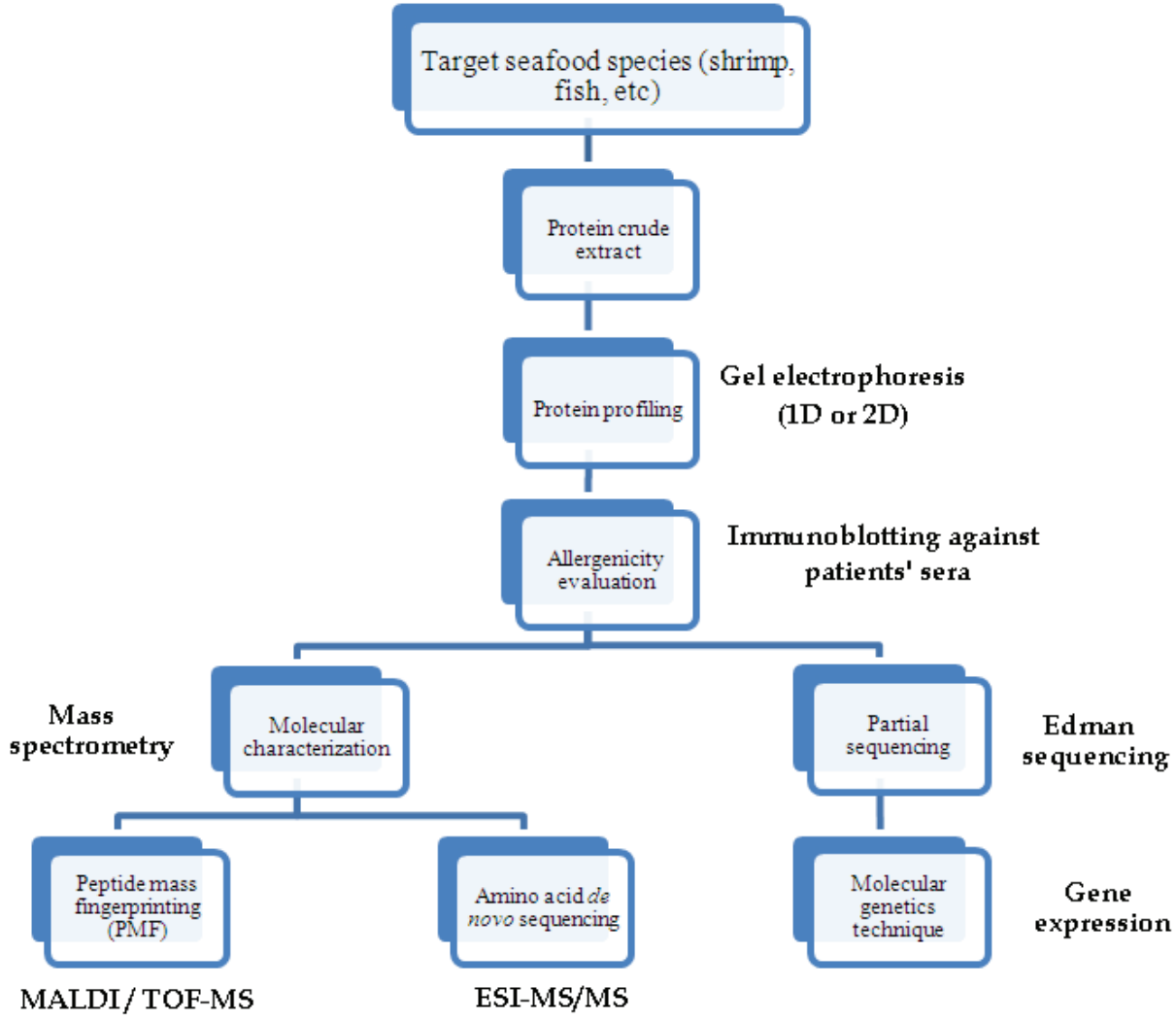

Fig. 2. The allergen discovery platform: starting from the seafood meat and ending by the characterization and quantification approaches

\section{1 protein profiling and the allergenicity evaluation}

\subsubsection{Protein separation using gel electrophoresis}

To characterize seafood allergens, it is necessary to profile the complex crude extracts by separating the protein content by gel electrophoresis. This technique plays a central role in seafood allergen research, wherein it provides a powerful separation and semi-quantification information. The principle of separation by gel electrophoretic techniques is mainly based on the ability of molecules to move through the pores of the gel media under the influence of an electric field. In this experiment, proteins carry charges from either a uniform coating by sodium dodecyl sulphate (SDS) or its natural net charge state isoelectric point (pI). The rate of protein mobility is based on the protein size and pI in both sodium dodecyl sulfate polyacrylamide gel electrophoresis (SDS-PAGE) and isoelectric focusing (IEF), respectively, where the larger difference in mobility gives better resolutions (Kinter \& Sherman, 2000). Combining both electrophoresis separation behaviors, SDS-PAGE and IEF, gives better resolution and sensitive detection of allergen profile. In two dimensional gel electrophoresis (2-DE), the first dimension separates proteins based on their $\mathrm{pI}$ and consequently, the IPGstrip 
of isoelectric focusing gel is saturated in SDS buffer and then applied to the SDS-PAGE, as the second dimension. The resulting gel profile shows $\mathrm{pI}$ values on the abscissa and the molecular weight along the ordinate. These two sources of information are very important in identifying proteins and comparing different profiles originating from different species. In addition, the 2-DE profile gives a relative amount of the allergens in each single spot (Rabilloud, 2000).

\subsubsection{Western blotting}

After separating the complex of proteins that might contain allergens by gel electrophoresis, the separation profile should be applied to the immunoblotting experiment using allergic patients' sera. Immunoblotting is a powerful, selective, and sensitive technique, used to detect a small amount of protein or to study antibody-antigen reactivity. The protein profile in gel electrophoresis is electrophoretically transferred to a membrane which is usually nitrocellulose or polyvinylidene fluoride (PVDF). The membranes are soaked with a blocking reagent, either bovine serum albumin or skim milk in tris-buffered saline (TBS), to prevent any non-specific binding of the primary antibody on the membrane (Habsah et al., 2000). Consequently, the blot is incubated with sera collected from individuals who have tested positive in the skin test (Abdel Rahman et al., 2011; 2010b). After that, the peroxidase-conjugated antihuman IgE secondary antibody is added for the purpose of visualization (Towbin et al., 1979). Then the color development substrate is added in solution to visualize the immuno-reacted bands. Once the allergen is identified, the antibody against this protein can be produced in animals such as rats, rabbits, or goats.These allergen specific antibodies can subsequently be used for cross-reactivity studies and for developing quantitative approaches that will be discussed later.

This basic profile is very important to determine the target allergenic protein, which can subsequently be further analyzed with different techniques for further molecular characterization using molecular cloning or MS techniques. The allergen bands could be cut and introduced to Edman sequencing to identify the amino acid sequence of the N-terminal protein region. This information is very important to develop the primers that will be used for producing a recombinant protein from the related gene. The Edman sequencing can be omitted if the allergen is identified as being related to other known allergens.

\subsection{Edman sequencing}

Edman sequencing was in the past the only technique to identify the amino acid sequence of the N-terminus of seafood allergens, which is necessary to design the appropriate primers for isolating the relevant gene and deoxyribonucleic acid (DNA) sequencing (Ayuso et al., 2008; Hamada et al., 2004; Ma et al., 2008). The Edman reaction is performed on the protein $\mathrm{N}$-terminus, where the amine side of the $\mathrm{N}$-terminal amino acid reacts with phenylisothiocyanate (PITC) to form a phenylthiocarbamyl (PTC) protein. Consequently, trifluoroacetic acid is used to cleave the PTC, which then gives phenylthiohydantoin (PTH) amino acid derivatives as final products. These final products have different chemical structures, depending on the side chain of the N-terminal amino acid, and can subsequently be separated by high-performance liquid chromatography (HPLC) and compared to a standard to identify the N-terminal amino acid. Through this reaction, the N-terminal amino acid is removed from the protein, and produces a cleaved derivative of that amino acid along with a protein that is shortened by one amino acid and has a new N-terminus. This shortened protein is re-exposed to the same procedure for removing the next amino acid (Findlay et al., 1989). Edman degradation is a part of modern protein analysis because of its ability to sequence a 
protein in its intact form as well as the proteolytic peptides. Furthermore, Edman sequencing has many other advantages, making it the main technique used worldwide in the last few decades before the use of mass spectrometry (MS) took over this kind of analysis. Advantages include its sensitivity, which is sufficient for analyzing proteins detected by Coomassie staining, the ease of operation, and the clarity of the data. However, this technique has a number of serious drawbacks compared to tandem MS, which will be discussed later, to be used in a proteomics platform. The time required to accomplish each cycle is very long ( 45 $\mathrm{min} / \mathrm{amino}$ acid) and it cannot be used with proteins having blocked N-termini (Kinter \& Sherman, 2000). However, Edman sequencing was the only technique to identify the amino acid sequence of the $\mathrm{N}$-terminus of seafood allergens, which are necessary to design the proper primer for isolating the relevant gene and DNA sequencing.

\subsection{Sequencing of proteins by cDNA analysis}

After collecting the N-terminus amino acid sequence of the target protein, specific DNA primers are designed for amplifying the equivalent gene using polymerase chain reaction (PCR). The complete amino acid sequence of the target allergen is deduced from the DNA sequence of its equivalent gene(s) for the isolated genome. A recombinant protein from the target gene can be produced inside bacteria. After the gene amplification, a restriction enzyme is used to produce staggered cuts on the specific sequence of one of the gene strands. The same enzyme is also used to have a complementary cut on the bacteria plasmid. The gene is incorporated in the plasmid sequence by insertion, where the cohesive ends are bound and form a full plasmid. While the bacteria are cultured, the gene is transcripted, translated, and then produces the target protein. The recombinant allergen is isolated from the bacteria-media complex using some affinity techniques such as affinity chromatography or immuno-precipitation (Reese et al., 1997; Swoboda et al., 2002). This protein should have the same allergenicity and identity as seen in the native protein that was extracted from the seafood meat.

\subsection{Characterization of seafood allergen using molecular genetics approach}

The molecular genetics based-method is followed by the allergen discovery, which is based on the charcterization of its primary structure. The first shellfish allergen characterized was from the shrimp (Hoffman et al., 1981), where the target allergen was applied to a crossed immunoelectrophoresis technique against rabbit and pig antisera. In that time, the identity of the allergen was limited to its reactivity with the patient sera, native and reduction size, the molecular contents, such as carbohydrates and amino acids, and the isoelectric point (Hoffman et al., 1981). Using the same molecular information, cross-reactivity studies between shrimp extracts with other species were commenced with homology ranging from $60-80 \%$ among the sequenced peptides (Halmepuro et al., 1987; Lehrer et al., 1985; Lin et al., 1993). The 36-kDa allergen was identified as TM by comparing the molecular characterization of Pen a 1 with the fruit fly (Drosophila melanogaster) (Daul et al., 1994). This study gave a remarkable movement in allergen characterization by comparing experimentally the known allergen's structural features with other species' known proteins (Table 2). Among different fish species, another cross-reactivity study was commenced with more molecular identification (Van der Ventel et al., 2010). The Atlantic cod major allergen Gad m 1 (Aas \& Elsayed, 1969) was identified as parvalbumin, by profiling the protein in isolectric focusing, SDS-PAGE, immunoblotting, and later identified using a recombinant form in Atlantic salmon (Do et al., 1999; ONeil et al., 1993; Pascual et al., 1992). The primary structure of the major shrimp 
allergen Met e 1, was also identified for the first time by a cloning technique, nucleotide sequencing, and translation to the amino acid sequence (Leung et al., 1994). Allergenicity of the recombinant protein was subsequently examined using the same protocol that has been used for the fish allergen discovery. After applying this informative strategy, the seafood allergen characterization, a new era in the field of seafood allergy research has begun. Other research groups started to focus on other novel allergens from mollusks, such as $49 \mathrm{kDa}$ which is known as Hal m 1 (Lopata et al., 1997), and to study the cross-reactivity among different species: lobster (Zhang et al., 2006), crab (Leung \& Chu, 1998) and among shellfish; crustaceans and mollusks, such as squid (Miyazawa et al., 1996). Motoyama et al., used the gene cloning technique to identify the reactive TM protein in six species of crustaceans using immunoblotting against sensitized patient sera and also a specific monoclonal antibody (Mabe et al., 2009; Motoyama et al., 2007).

\subsection{Protein mass spectrometry}

Mass spectrometry is a technique used to characterize the gas-phase chemical structure of compounds after having them ionized. Based on the ion source, the ions in mass spectrometer can be formed in either of five different mechanisms: protonation, deprotonation, electron capturing, electron ejection, and adduct formation. The molecular ions, positive or negative, are electrically attracted and focused to get them in the mass analyzer, where the ions are separated based on their mass-to-charge ratio $(\mathrm{m} / \mathrm{z})$. This experiment usually gives the molecular weight of the target compound. For further structural analysis, tandem MS is performed by separating the target ions in the first mass analyzer, and then exposed to the collision cell. The produced fragment ions are separated in the second mass analyzer based on their mass-to-charge ratio to give a chemical structure.

Analyzing large molecules using tandem MS was only possible for the energetic stable molecules, such as polymers. Proteins were analyzed by MS after the invention of the matrix-based laser desorption techniques, like fast atom bombardment (FAB) and matrix assisted laser desorption ionization (MALDI), where the laser energy transferred indirectly and softely to the protein via the matrices. Although, MALDI and time-of-flight (TOF) is a good combination between an ion source and mass analyzer for protein MW determination, generating a fragmentation pattern for the protein's ion is a challenge. This dilemma is limited to the fact that the MALDI mainly forms mono-charged ions, which requires higher energy in acceleration voltage for the effective fragmentation process, as well as the difficulties of coupling a TOF MS to another analyzer for tandem process. The electrospray ionization (ESI) invention offered a historical shift for protein characterization using MS, where this ion source produces the multiply charged ions with lower demand on fragmentation energy. The primary structure of the allergenic proteins can now be identified using MS, where it helps to understand the other proteins' structural features and functional activity. In addition, the amino acid sequence directly corresponds to the DNA sequence of the corresponding gene (s), which helps to study the activity of proteins by detecting the common mutations at the molecular level.

Amino acid sequencing is performed by determining the structure and the position of each amino acid residue within the protein. This target demands a method sensitive and specific enough to analyze native proteins in highly throughput manner. In addition, it must provide reliable information with sufficient mass accuracy (Kinter \& Sherman, 2000). The ESI generates multiply-charged ions, which are easily accelerated and fragmented in tandem 
MS experiments. Allergen analysis can be performed in MS by peptide mass fingerprinting (PMF) as an identification technique or by tandem MS for de novo sequencing.

\subsubsection{Peptide mass fingerprinting.}

Mass spectrometry has become a major analytical tool for protein structural analyses. Generating the gas phase ions of protein molecule was a challenge before MALDI and ESI along with accurate mass analyzers, which offered a valuable tool for protein identification. Following the completion of the early genome sequencing projects, several search engines (i.e. Mascot and Sequest) were developed for the genome databases with MS interface. The enzymatic digested protein generates a highly unique peptide profile which is further analyzed by MS. These peptides are introduced to a mass spectrometer to give fingerprint profiles. The so called PMF technique is important for protein identification that already has genetic information in the databases. There are several factors that control the precision of the database search such as the resolving power of the MS, type of protease, availability of the gene data in data bank, and the purity of the target proteins (Aebersold \& Mann, 2003).

\subsubsection{Tandem mass spectrometry}

Selected gas-phase ions of peptides and proteins are fragmented in the tandem MS mode, which gives a series of ions related to the amino acid sequence. This development in protein MS was extended to give high throughput protein identification, de novo sequencing, and identification of post-translational modifications (Aebersold \& Mann, 2003). Protein tandem MS-based techniques are mainly divided into two major types; bottom-up or top-down. These terminologies are assigned for the point of sample handling before MS analysis and from the data processing and sequencing manipulation (Kinter \& Sherman, 2000).

\subsubsection{Bottom-up approach}

In the bottom-up approach, the enzymatically-digested proteins are subjected to LC-MS/MS analyses. The precursor ions of the peptides are separated in the first mass event, and then fragmented to produce a series of informative product ions. These ions are separated and analyzed in the second mass event.

A distinctive series of product ions are directly related to the amino acid sequence, which then compared with 'in-silico' ions that are generated theoretically from the DNA databases by computers. The sequence will be assigned when both series of ions, experimental and theoretical, are matched perfectly as shown in peptide number 3 in Fig.3. This technique usually provides useful information about the post-translational modifications (i.e. phosphorylated, acetylated). Some of these post-translational modified residues are difficult to be identified due to poor chromatographic resolution or detector sensitivity (Chait, 2004; Scherperel \& Reid, 2007), as seen for the two peptides number 2 and 5 in Fig. 3. On the other hand, introducing the whole protein to the mass spectrometer without any digestion, top-down (discussed below), is a very useful technique to identify most of the labile post translation modification groups with high amino acid sequencing coverage (Siuti \& Kelleher, 2007).

Enzymatic digestion of the intact protein followed by purification and electrophoretic separation prior to MS analyses is routine but tedious work for bottom-up approach. The enzymatic peptides are normally separated by reversed phase chromatography and subjected ESI or MALDI with analysis by tandem MS. The sequence of each peptide is deduced from the product ion spectra after gas phase collision induced dissociation (CID) (Kinter \& Sherman, 2000). 
Generating a good sequencing coverage for the intact protein requires producing peptides that are readily soluble for chromatography. The chromatographic separation of peptides prior to MS ionization is very important. Generating ion of highly energetic gas-phase ions inside the field free region is required for facile fragmentation or dissociation. Sequencing the intact protein using a regular tandem mass spectrometer is limited to the energy of the dissociation and the resolving power of the mass analyzer, which leads to erroneously manipulation from the algorithms of the database. The labile post-translational and environmental modifications of proteins are difficult to be identified using energetic dissociation bottom-up method. As well the modified peptides are more sensitive to be detected by MS than the large hydrophobic proteins (Eidhammer et al., 2007). The bottom-up approach can usually deal with most types of proteins regardless of their size or function. This approach is still the most common, but the sequence coverage is limited (Eidhammer et al., 2007).

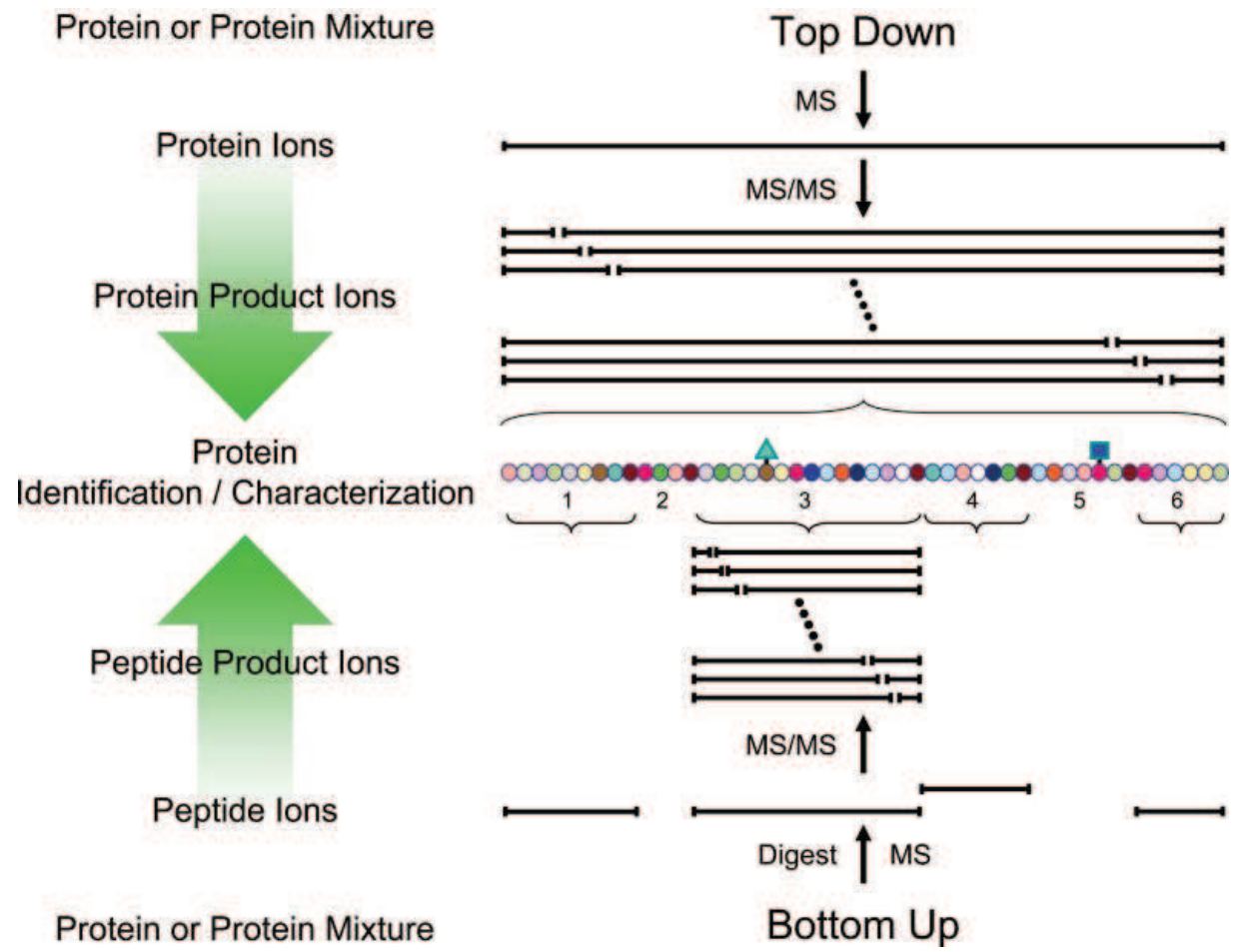

Fig. 3. Schematic overview of bottom-up and top-down approaches employed for tandem MS-based protein identification and characterization. The shaded circles represent the amino acids of a protein, while the shaded triangle and rectangle represents post-translational modifications. (Reproduced by permission of The Royal Society of Chemistry; (Scherperel \& Reid, 2007)

\subsubsection{Top-down approach}

Manipulating the bottom-up approach data requires data availability in the gene bank. Thus, the top-down approach was found to improve protein identification even in case of 
the lack of genetic information in the databases. Understanding the chemical composition, molecular weight, and stability/solubility of the target protein(s) is paramount for achieving proper ionization and gas phase dissociation in the mass spectrometer. Kelleher and group introduced the top-down approach by analyzing an intact protein using an ESI ion source (Kelleher et al., 1999). This type of analysis requires high resolution mass analyzers as well as a high energy collision cell. The amino acid sequence, and post-translation modification structures were determined in this approach using in-time tandem MS experiments. The mass difference between the generated precursor ions and their equivalent predicted ions in the DNA databases were considered for amino acid sequencing of the intact protein (Reid \& McLuckey, 2002).

The top-down approach was further developed for the analysis of a mixture of proteins without classical separation (chromatography or electrophoresis). The precursor ion of the target protein is selected and isolated in the first mass analysis event for amino acid sequencing (Reid \& McLuckey, 2002). This approach still offers a comprehensive post-translation modification mapping. Several bioinformatic tools can be implemented to map the post-translation modification information in protein, which are mainly defined by the mass differences between the experimental and theoretical spectral data (Kelleher et al., 1999). The MS resolution is high enough to identify a disulfide bond, which increases the molecular weight of the protein by $2 \mathrm{Da}$ after reduction. The top-down method has clearly been shown to identity even the labile post-translation modification groups (Scherperel \& Reid, 2007). Two-dimensional correlation between MS/MS and MS/MS/MS was also developed to confirm the amino acid sequence in Fourier-transform ion cyclotron resonance (FTICR) instruments (Zhang \& McElvain, 2000).

The top-down approach affords another valuable and powerful tool for proteomic analyses. Post-translation modification mapping can become a reliable tool for determining chemistry, location, and quantity of these modifications along with the primary structure of a protein. Using this method as the sequencing approach for an intact protein can provide close to $100 \%$ coverage. Moreover proteins can be part of a mixture, or have unusually large molecular weight. Analysis of these types of samples will still give the same accuracy and with less complexity compared to the bottom-up approach. Simple algorithm databases with more sophisticated data processing are readily available for top-down approaches. Including powerful and advanced MS instruments such as FTICR allowing for maximum mass accuracy and resolution reinforces the strength behind this approach

\subsection{Characterization of seafood allergen using mass spectrometry}

Mass spectrometry serves as a characterization technique of seafood allergens by determining the molecular weight, the primary structure, and the quantity of the intact allergenic protein. Unfortunately, a number of seafood allergen research articles that used MS is quite low compared with other protein-based food allergen research. The shortage of genomic data for many of the seafood species in GenBank and lack of expertise in facilitating the MS techniques in this research area are also the main reasons for this literature shortage. Officially, MS was recommended as a replacement technique for allergen detection in inspection labs back in 2005 (Hungerford, 2006; Hungerford \& Trucksess, 2005).

Allergen analysis by MS started by determining the molecular weight of small allergens such as parvalbumin (12 kDa) in fish (Bugajska-Schretter et al., 2000; Cai et al., 2010; Swoboda et al., 2002). After completing the genome sequence and developing the MS-interface databases, some studies use the PMF approach to identify the seafood allergens evaluated 
by immunoblotting (Ayuso et al., 2009; García-Orozco et al., 2007; Mazzeo et al., 2008; Shen et al., 2011; Yamasaki et al., 2010; Yu et al., 2003). The best example of this kind of research was in 2003, when Pen m 2 shrimp allergen was identified using PMF, where the recognized spot proteins by a pool of patients' sera were tryptic digested and analyzed by MALDI-ToF (Yu et al., 2003). Consequently, the purified AK of white shrimp that was partially sequenced using the shot-gun MS method (García-Orozco et al., 2007) was also identified by comparing the MS data with the sequence of Pen $\mathrm{m} 2$ in the MASCOT search engine. Instrumentally, most of this unambiguous characteristic information was generated by coupling MALDI ion source to the TOF mass analyzer, which can give the molecular weight of the purified intact protein with a margin of error of $0.1 \%$ (DeHoffmann \& Stroobant, 2007) and perform the PMF experiments. The precision of MALDI-TOF is poorer with larger proteins, which provoked to use more advanced ion sources like ESI coupled with FTICR (Ma et al., 2008). The high resolution of MS analyzers are used to study seafood authentication by measuring the exact molecular weight of a marker protein (Mazzeo et al., 2008).

The seafood allergenic proteins can be also sequenced using tandem MS (Abdel Rahman et al., 2010a; 2011; 2010b; Misnan et al., 2010). This method was used in the seafood allergen studies as a confirmatory technique to study some biochemical and biophysical properties by collecting the amino acid sequence of a few peptides (Perez-Gordo et al., 2011). Ma et al. (2008) validated the using of high resolution MS profiles to evaluate the cross-reactivity of the allergens based on their structural similarities. The cross-reactivity between both the natural and recombinant forms of cod and carp parvalbumin was evaluated using patients' sera and the structure was also evaluated using both circular dichroism (CD) and nuclear magnetic resonance (NMR) (Ma et al., 2008).

In Helleur's group, the tandem MS technique was the method for de novo sequencing of seafood allergens. Tropomyosin, the major snow crab and black tiger prawn allergens, was used as a reference protein to develop a tandem MS strategy for the protein sequencing (Abdel Rahman et al., 2010a;b). Since the amino acid sequences of both allergens are available in the databases, it was an advantage to optimize the full sequence strategy. The multi-enzymatic digestions, multi-ion sources, and multi-derivatization reactions were used for obtaining the full amino acid coverage. This strategy was later applied for other allergens characterization (Abdel Rahman et al., 2011; Carrera et al., 2010; Liu et al., 2011). The high resolution tandem MS is also capable to study the heterogeneity of allergen isoforms in micro scale. Permyakov et al. studied the microheterogeneity of Pike $\alpha$-parvalbumin, where precisely the MS output shows the presence of both amino acid sequences for $\alpha 1$ and $\alpha 2$ isoforms (Permyakov et al., 2009). Extensively, 25 new parvalbumin isoforms were identified and de novo sequenced from different 11 species using some bioinformtic tools (e.g. PEAK). The high mass accuracy of the FTICR (0.05-4.47 ppm) allowed for the amino acid sequence of the species which their genomes remain unsequenced (Carrera et al., 2010).

\section{Allergen quantification}

\subsection{Immunological-based techniques}

There are several techniques that can be used for the quantification of potential allergens. These techniques target either the allergenic protein itself or biomarker that indicates its presence. However, the allergen detection itself is a challenge, as their chemical properties are not be well characterized. In addition, many allergenic seafood species contain multiple allergenic proteins that can vary in their concentration. Once the allergenic protein is characterized and a specific antibody produced, this allergen can be routinely detected in 
one of the immunochemical detection protocols such as radio-allergosorbent test (RAST), enzyme allergosorbent test (Dearnaley et al., 2010), rocket Immuno-electrophoresis (RIE), immunoblotting, and enzyme-linked immunosorbent assay (ELISA). Whereas, RIE is only used for qualitative or semi-quantitative the same as immunoblotting, however, RAST, EAST, and ELISA are absolute quantitative methods. The choice of method depends on the availability of the antibody, the target of the analysis, and the method characteristic merits such as detection limit and precision.

\subsubsection{Radio-allergosorbent inhibition}

Radio-allergosorbent is a technique that can be used for the determination of allergen-specific $\mathrm{IgE}$ antibodies generated by the sensitized individuals, which is commonly used in the clinical diagnosis of most allergies. In addition, this technique has been used for the qualitative detection and determination of allergenicity of different seafood species. Basically, the target allergen in the RAST test is bound to a solid polymer. The specific $\operatorname{IgE}$ in the patient sera binds to the allergen. After removing non-specific IgE, antigens in a sample solution inhibit IgE binding to the antigen immobilized on the solid phase. Radio-labeled anti-human IgE antibody is added to form a complex, and then the unbound secondary antibody is washed away after incubation. The amount of radioactivity, detected in gamma counter, is proportional to the amount of the bound IgE (Malo et al., 1997). These methods have several drawbacks to be the major technique for allergen quantification, one of them is its reliance on human sera from allergic individual (Nordlee \& S.L.Taylor, 1995)

\subsubsection{Enzyme-linked immunosorbent assay.}

Currently, ELISA is the main immunological reaction-based technique used for determination levels of allergens in different matrices. In principle, a calibration curve of a serial dilution from the allergen extracts is developed and the antigen/antibody reaction is optimized. There are two main approaches for allergen quantification using ELISA: competitive and sandwich. The sandwich ELISA is more specific and precise than the competitive, where the primary antibody is bound to the solid phase like the microtiter plate. The specific protein is captured and the non-bound species will be removed. The captured protein is detected by the enzyme-labeled secondary antibody. The complex is visualized by a reaction between a particular substrate with the conjugated enzyme on the secondary antibody and developing a colored product. The analyte concentration is proportional directly with the measured absorption. The relatively small proteins are preferably measured by the competitive ELISA. The patients' sera and the allergen extracts are pre-incubated, and then this mixture is added to the microtiter wells that have an antigen bound to the solid phase. The maximum binding between the solid phase-bound antigen and the enzyme-labeled antibody is performed when there is no antigen presence in the inhibitor sample. Antigens in the sample inhibit the binding of enzyme-labeled antibody to the immobilized antigen, where the concentration of the allergen is inversely proportional to the color absorption.

\subsubsection{Detection and quantification of selected allergens in seafood}

The RAST technique was used as a diagnosis method, where the positive skin test patient sera were evaluated using a crude extract of the potential allergenic seafood, such as in crustaceans, prawn, shrimp, crawfish, and lobster (Daul et al., 1988; Halmepuro et al., 1987; Nagano et al., 1984). This technique was used to study the cross-reactivity between the oyster and crustacean (Lehrer \& McCants, 1987) and caddis fly with arthropoda and mollusca (Koshte et al., 1989), 
which indicated to the non-specificity of RAST to be a diagnostic assay. However, the RAST inhibition technique was used to evaluate the species-specific shrimp allergen (Morgan et al., 1989). Shrimp allergy is estimated to be about $2 \%$ of the general population (Besler et al., 2001; Lopata et al., 2010). The threshold doses for shrimp allergic individual were evaluated to be $16 \mathrm{~g}$ (Daul et al., 1988) and for fish ranging from 5-600 mg (Taylor et al., 2002) using the double-blind placebo controlled food challenges (DBPCFC). Cod fish allergen, the first reported allergen, was also evaluated by RAST to study the physico-chemical properties and the cross-reactivity with other fish species (Aas \& Elsayed, 1975; Aas \& Lundkvist, 1973; Aukrust et al., 1978).

The absolute quantification for the seafood allergen was initiated in 1997 by Lehrer's group (Jeoung et al., 1997). A sandwich ELISA method was developed using TM extracted and purified from brown shrimp. The detection limit was $4 \mathrm{ng} / \mathrm{ml}$ and the assay detected the TM-like allergen in different crustacean species such as crab and lobster. Recently, the method was optimized to evaluate the level of crustacean major allergen, TM, in processed food (Motoyama et al., 2008; Seiki et al., 2007) with a limit of detection of about $2.5 \mathrm{mg} / \mathrm{kg}$ (Rejeb et al., 2002). This assay demonstrated cross-reactivity between other crustaceans like crab and lobster. Although the TM sequence homology between the shrimp and pork or chicken was around 55\%, this study showed no cross-reactivity between them (Reese et al., 1997). The fish major allergen, parvalbumin, was quantified for the first time by Lopata et al (2005) in its aerosolized form (Lopata et al., 2005). Recently, this method was applied for the evaluation of fish allergen levels in foodstuff (Faeste \& Plassen, 2008), and for comparing the parvalbumin levels in different species (Kuehn et al., 2010). Commercially, there is only one ELISA kit available for detection of crustacean' allergens in foodstuff: however there is none available for the fish allergens.

\subsection{Allergen quantification using mass spectrometry}

Studying the large variety of proteins belonging to a certain biological system is known as proteomics. In recent decades, high throughput MS-based proteomics techniques have been developed for protein analysis and identification. The tandem MS tools have been very influential in the field of protein science as the genome sequence projects were being completed. The discovery and development of ESI and MALDI sources has given protein MS a huge push to become one of the dominating fields in proteomics. At its inception, MS proteomics research was mainly a qualitative discipline, where the outputs were limited to a list of identified proteins without any further information about abundances, distributions, or stoichiometry (Schulze \& Usadel, 2010). In contrast, quantitative strategies were developed by analyzing the gene expression by microarray technology, real-time PCR, or evaluating the enzymes' activity that directly represent theirae quantity. Several MS-based tools are being developed for proteomics quantification, which help in characterizing the proteome complexities. For example, quantitative data can assist in the study the true protein interactions (interactoms) of a given bait protein over the background. These proteomics strategies are used to differentiate between stressed and normal samples or between knock-out and wild types for certain biological systems.

\subsubsection{Proteomics quantification}

Quantitative proteomics approaches are used as part of the larger framework of the available techniques for studying regulatory processes in the living cell. Choosing the quantification method is less important than the method's practical aspects which include good technical 
reproducibility. By the same token, the biological system variations must be considered in the experimental design, along with financial costs. Since there is no amplification step at the protein level, the sample size is the most important limiting factor affecting the strategy of quantitative differential proteomics. Accordingly, enrichments and purification of protein are carried out to meet the sensitivity of the quantification technique. In this way, the sample size will influence the choice of analytical method (Schulze \& Usadel, 2010).

The differences in the physical and chemical properties of different peptides, directly affect the proton affinity and the MS signal intensity. These peptide variables are their charge state, peptide length, amino acid composition, and any post-translational modification. These structural variations contribute to the peptides' ion intensities even if they belong to the same protein. Because of this, many MS-based quantitative methods produce only relatively quantitative data, which is based mainly on the MS response in contest with its sample matrix. Accordingly, careful experimental design and suitable data analysis are needed to obtain the desired analytical information.

\subsubsection{Relative quantification MS-based techniques}

The relative quantification MS-based techniques are categorized into two major groups: stable-isotope-labeling and the label-free approach. The relative standard deviation for most stable-isotope-labeling techniques is below $10 \%$ and the accuracy is approximately $30 \%$, based on peak intensities or extracted ion chromatograms. However, the precision obtainable from label-free approaches, based on spectral counting or derived indices, is as high as $50 \%$ RSD (Schulze \& Usadel, 2010).

The label-free quantification methods are based mainly on precursor signal intensity, which requires a high precision mass spectrometer. The label-free approaches are inexpensive (no labeled material to purchase) and can be applied to any biological material. The proteome coverage for quantified proteins can be very high, because any protein with one or more identified peptides can be quantified. Thus the sample complexity does not normally increase by mixing different proteomes together. Hence the protein expression can be quantified between different biological samples from different treatments. These samples can be analyzed by the free-label MS approach due to its analytical power and flexible dynamic range (Old et al., 2005). There are two main label-free approaches; protein-based methods (spectral count or derived indices) and peptide-based methods (ion intensities and protein correlation profile). The protein-based method looks to the protein expression levels among proteins of the same sample and compares them with another sample. In contrast, the peptide-based method utilizes the averaged and normalized ion intensities of the identified peptides (of specific proteins) for quantification.

The isotopic-labeling methods are classified with respect to the labeling strategy; metabolic labeling and isobaric mass tags. The metabolic labeling approach introduces the whole cell or organism to a labeled culture media (e.g. stable-isotope labeling by amino acid (SILAC) in cultured cells). On the other hand, chemical labeling (isobaric mass tags) can be attached to the protein or proteolytic peptides by a chemical reaction. Equivalent quantities of the labeled and unlabeled samples are mixed and treated in the same manner prior to the MS analysis. The differences between the labeled peptides' intensities and those of unlabeled represent the levels of that specific protein in the original sample. The drawback in this method is interference by co-eluting isobaric compounds when tandem MS is not used.

The isobaric mass tags method can overcome any co-eluting interferences by developing reagents that co-elute with the target peptide ion, then they will have a significant resolution 
after fragmentation in the product ion spectra. Each product ion spectrum is the result of a different chemical tag with its intensity equivalent to the level of protein expression in the original sample. These fragments (tags) are in the low mass range, which make interferences from other peptides' fragments difficult. There are some commercial isobaric reagents that offer this type of quantification strategy such as the isobaric tag for relative and absolute quantification (iTRAQ) and the tandem mass tag (TMT).

\subsubsection{Absolute quantification and isotopic dilution mass spectrometric techniques}

A technique called absolute quantification (AQUA) using the stable-isotopic-labeled technique was reported for the first time by Desiderio and Kai (1983) (Desiderio \& Kai, 1983). By using selected reaction monitoring (SRM) in triple quadruple tandem mass spectrometer, the AQUA became a standard protocol in protein quantification. The informatics combination between the retention time, peptide precursor ion, and the fragmentation profile gives this method high specificity toward the particular target peptide. The signal-to-noise ratio in SRM is very high, which gives an extended linear dynamic range up to 5 orders of magnitude. By spiking a protein sample with a known amount of the stable-isotopic-labeled peptide, the concentration of the native protein can be calculated. However, this may not cover all levels of the expressed protein in the tissue, because sample preparation steps may lead to loss or enrichment of the target peptide that are not addressed by the AQUA method. The absolute quantification of large proteins (MW $>15 \mathrm{kDa}$ ) by $\mathrm{MS}$ can be performed using the bottom-up approach. The intact protein is digested and the signature peptide is selected to represent the target protein. The stable-isotopic-labeled and natural (light) forms of the signature peptide are chemically synthesized, where the heavy form is used as an internal standard. Before MS analysis, the heavy form of the signature peptide is added to the sample in a deliberate manner; hence the method is called 'isotope dilution' MS. Small proteins $(<15 \mathrm{kDa})$ can also be quantified using the top-down approach, whereby the internal standard is prepared as a metabolic labeling strategy using labeled culture media (Brun et al., 2009).

\subsubsection{Validation of bioanalytical methods}

Once the AQUA method for the target protein is developed, the validity of the method is studied and evaluated to meet successfully the minimum standards of the Food and Drug Administration (Marko-Varga et al., 2005) guidelines for accuracy, precision, selectivity, sensitivity, reproducibility, and stability (Food and Drug Administration, 2001). This guideline was specifically developed for studying the bioanalytical method validation of small molecules or drugs, however, Helleur's group has modified this protocol to be developed for studying the AQUA method for allergen quantification using multiple reaction monitoring (MRM) tandem MS (Abdel Rahman et al., 2010c).

\subsubsection{Insight of using mass spectrometry for seafood allergen quantification}

The seafood allergen discovery platform, starting from the seafood species and ending by allergens absolute quantification, can be expedited efficiently by applying the allergenomics approach as discriped in Fig 4. Allergenomics is one of the functional proteomics strategies that focus on potential allergen discovery of such species. Whereas the primary structure and the relative and absolute quantification of the target allergen are determined. This strategy gives a reliable tool for monitoring the immuno-reactivity proteins in various conditions such as heating or adding food additives. Helleur's group commenced this strategy in seafood allergen, where the snow crab and black tiger prawn were the species of choice 
(Abdel Rahman et al., 2010a;b). The real seafood allergen quantification by MS was performed for measuring the level of aerosolized snow crab major allergens in the workplaces. The TM and AK were simultaneously measured using MRM-MS/MS in air samples collected from crab processing plants (Abdel Rahman et al., 2012; 2010c) and from fishing vessels as joint project between SafteyNet and Rural Center at Memorial University of Newfound land and Dalhousie University, respectively (in preparation).

For developing allergenomics quantification method for any species, the crude extract samples should be profiled in 2D-gel electrophoresis (Fig. 4). The allergenicity of the protein profile is evaluated by immunoblotting the 2D-gels with a pool of patients' sera. The reactive proteins would then be cut, tryptic digested, and characterized using MS. The relative abundances of the discovered allergens can be evaluated using either the label-free or the isobaric mass tags methods such as iTRAQ. It is highly recommended to have an allergenomics profile and absolute multi-allergens quantification method. Therefore, proteomics quantification methods such as iTRAQ or TMT can be used to give a relative quantification profile for all detected allergens in a very specific and sensitive manner. All candidate allergens that have been shown up in the iTRAQ profile will be considered for developing an absolute quantification method. An artificial polypeptide is designed to produce all the signature peptides of all target allergens as soon as digested by trypsin. The heavy form standard of this polypeptide is added to the target sample (e.g. food or air filters), as an internal standard right before the extraction and digestion. Stoichiometrically, this process will control completeness of the digestion and sample loss as well as give an absolute quantification for each single allergen in the sample in a single run. This approach can be performed in air samples as well as for monitoring the levels of allergens in food as a quality control test (food grades) for the sake of reporting the nutritional facts.

\section{Occupational/inhalant allergy and asthma associated with seafood}

The increasing growth of the seafood market in the past two decades has led to an increasing number of workers engaged in various harvesting and aquaculture activities. Aside from increased consumption worldwide, more than 45 million workers are also involved in seafood production and are therefore exposed to seafood allergens in various contexts (Food and Agriculture Organisation, 2010). Adverse reactions have increasingly been reported in individuals consuming, handling or processing seafood in various settings. Aside from the ingestion route, seafood proteins can also enter the body through inhalation of aerosols or vapours containing allergens.

In domestic settings, a Spanish study reported 11\% of children from a group of 197 children with fish allergy/hypersensitivity, placed on a strict fish avoidance diet, who experienced repeated allergic reactions upon incidental inhalation of fish odors or vapors. In most cases, these episodes occurred at home when other people were eating fish (James \& Crespo, 2007). A similar observation in a South African study of 105 individuals with self-reported seafood allergy, reported $30 \%$ of individuals with allergic symptoms after handling or inhaling seafood in the domestic home environment (Lopata \& Jeebhay, 2001).

In the workplace setting, occupational asthma was first reported in 1937 by De Besche in a fisherman who developed allergic symptoms when handling codfish. Since then various other seafood has been reported to cause occupational allergy and asthma including crustaceans as summarized in Table 1 (shrimp and shrimpmeal, prawn, lobsters), mollusc's (mussels, octopus, scallops, abalone) and other bony fish (trout, salmon, pilchard, anchovy, plaice, hake, tuna, haddock, cod, pollack). These incidents have been reported on board 


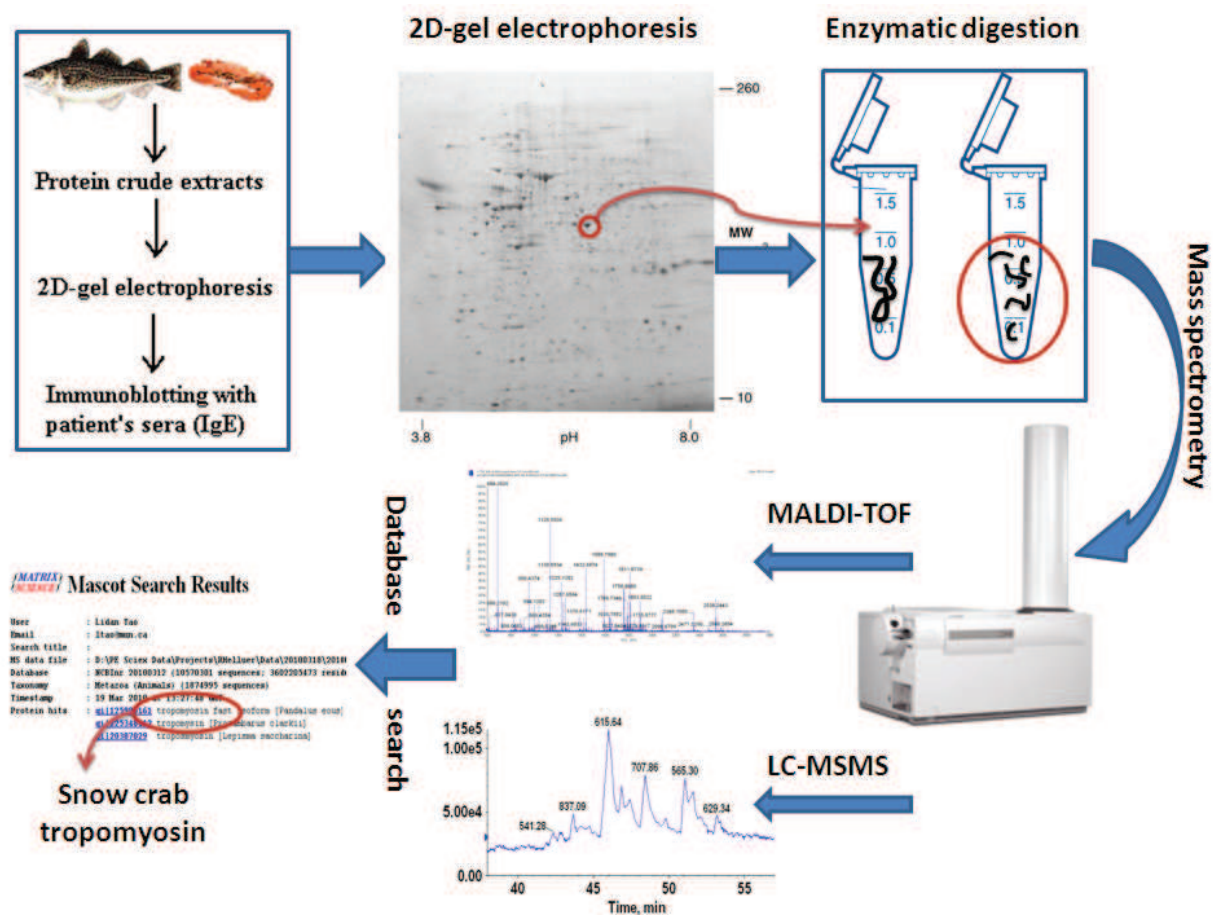

Fig. 4. The allergenomics strategy for allergen discovery, which uses the seafood crude extracts and the proteomics-MS based approach for characterization

fishing vessels and among workers involved with land-based seafood processing factories. Various epidemiological studies among seafood processors indicate that the prevalence of occupational asthma is between $2 \%$ and $36 \%$. These differences in prevalence are partly due to varying definitions of occupational asthma used by investigators; the allergenic potential of the seafood proteins involved; and the type of work process resulting in excessive exposure such as steam, organic dust, air blowing and water jets. What is notable, however, is that these studies show that occupational asthma is more commonly associated with shellfish (4-36\%) than with bony fish (2-8\%) (Jeebhay \& Cartier, 2010; Jeebhay et al., 2001).

Various studies show that the common work processes causing bioaerosol production include butchering or grinding; degilling, 'cracking' and boiling of crabs; cleaning and brushing of crab; 'tailing' of lobster; 'blowing' of prawn meat through shells; washing or scrubbing of shellfish; degutting, heading, and cooking/boiling of fish; mincing of seafood; and cleaning of the processing line or storage tanks with high pressured water hoses (Jeebhay et al., 2001). Processes that generate dry aerosol particulates such as prawn blowing operations using compressed air and fishmeal loading/bagging appear to generate higher levels of particulate than wet processes (prawn blowing with water jets). It is these aerosolized wet or dry particulates produced from seafood during processing operations that are inhaled by workers in the occupational setting. In domestic environments, it is highly probable that similar conditions prevail, although on a much smaller scale, resulting in allergic symptoms in highly exposed or allergic individuals. 
Experimental studies in crab processing plants demonstrate that the aerosols generated in these factories contain mainly crab exoskeleton containing chitin, meat primarily muscle protein, gills and kanimiso/internal organs (Jeebhay et al., 2001). Fish juice produced in fish filleting and canning plants has various biogenic amines, degradation compounds associated with postmortem changes, digestive enzymes, skin slime/mucin, collagen and fish muscle proteins.

\subsection{Aeroallergen quantification in seafood workplaces}

There are several quantification approaches utilized to measure the levels of aeroallergens in workplace environments. These techniques are based mainly on the immunoreactivity of allergenic proteins with the specific IgE of sensitized patients' sera. Inhibition RIA, RAST, and ELISA are the most common techniques that have been used historically. Taylor et al. measured the level of raw fish aeroallergens in open-air fish markets using the inhibition RIA (Taylor et al., 2000). In 1997 Malo et al. applied the RAST test for the first time to measure seafood aeroallergens, where the air samples were collected from snow crab processing plants (Malo et al., 1997). In this study, total allergen extracts were prepared as a standard and the activity of these extracts was evaluated by skin test in patients known to have occupational asthma. The amount of the allergenic protein was estimated by percent inhibition of the RAST profile. A comprehensive study with four snow crab plants was accomplished in Newfoundland and Labrador, where air samples were analyzed using a similar process (Howse et al., 2006).

Inhibition ELISA techniques have also been used to study seafood aeroallergens. The water or meat protein extract and a pool of patients' sera were used as standard and primary antibody, respectively. Weytjens et al. measured the levels of snow crab allergen in workplaces and studied the gradient profile of the aeroallergens inside a processing plant using the ELISA technique with an ${ }^{125}$ I-radiolabel (Weytjens et al., 1999). Using the same approach, Beaudet's group studied aerosolized crab levels aboard crab processing vessels in Alaska, where the concentration of crab allergen was reported to be similar across all job categories (Beaudet et al., 2002). ELISA techniques with a colorimetric detection system were developed for measuring the fish aeroallergen in processing plants (Lopata et al., 2005). In 2005, Jeebhay et al. quantified the level of aeroallergens to study the correlation between the levels of the aerosolized allergens and other major determinants of variability in an attempt to establish dose-response relationships for asthma due to fish antigen exposure (Jeebhay et al., 2008; 2005). Another comprehensive study was performed for examining the levels of bioaerosols in the seafood industry using the ELISA reader for quantification purposes (Bang et al., 2005). Recently, the aeroallergen levels of snow crab and northern shrimp in harvesting vessels and processing plants were measured directly using tandem MS techniques. The TM and the AK were detected in their aerosolized form in the processing plants; however, TM was the only allergen detected aboard the vessels holds and decks (Abdel Rahman et al., 2012; 2011; 2010c). Table 3 summarizes the results of the various exposure characterization studies conducted and demonstrates the wide range of total inhalable airborne particulate $\left(0.001-11.293 \mathrm{mg} / \mathrm{m}^{3}\right)$, protein $\left(0.001-6.4 \mathrm{mg} / \mathrm{m}^{3}\right)$ and allergen $\left(0.001-75.748 \mathrm{mg} / \mathrm{m}^{3}\right)$ levels (Jeebhay \& Cartier, 2010). Particulate and allergen levels reach very high levels in the processing operations aboard vessels at sea in the case of crab processing and during fishmeal operations.

In conclusion, the development of novel methods to characterize airborne seafood allergens have the potential to introduce accurate, sensitive, and specific advanced monitoring approaches that will contribute towards strategies to minimize allergen exposures among 


\begin{tabular}{|c|c|c|c|c|c|}
\hline & Seafood Category & $\begin{array}{l}\text { Particle fraction } \\
\text { measured }\end{array}$ & \begin{tabular}{|l|} 
Particulate \\
conc. \\
$\left(\mathrm{mg} / \mathrm{m}^{3}\right)$ \\
Range
\end{tabular} & $\begin{array}{l}\text { Protein } \\
\text { conc. } \\
\left(\mathrm{mg} / \mathrm{m}^{3}\right) \\
\text { Range }\end{array}$ & $\begin{array}{l}\text { Allergen } \\
\left(\mu \mathrm{g} / \mathrm{m}^{3}\right) \\
\text { Range }\end{array}$ \\
\hline \multirow{7}{*}{ 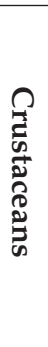 } & $\begin{array}{l}\text { crabs (snow, Tanner, } \\
\text { common, King) }\end{array}$ & total inhalable & $0.001-0.680$ & 0.001-6.400 & $0.001-5.061$ \\
\hline & crabs (snow)* & total inhalable & ND & ND & $0.001-5.061$ \\
\hline & $\begin{array}{l}\text { crabs (snow, Tanner, } \\
\text { common, King) }\end{array}$ & total inhalable & ND & ND & $0.079-21.093$ \\
\hline & prawns & total inhalable & $0.100-3.300$ & ND & ND \\
\hline & shrimp & total inhalable & ND & ND & $1.500-6.260$ \\
\hline & rock lobster & thoracic & LOD-0.661 & LOD-0.002 & ND \\
\hline & scampi & total inhalable & ND & ND & $0.047-1.042$ \\
\hline \multirow{9}{*}{ : } & salmon & respirable & $0.040-3.570$ & ND & $0.100-1.00$ \\
\hline & pollock & total inhalable & 0.004 & ND & ND \\
\hline & whiff megrim/hake & total inhalable & ND & ND & $0.002-0.025$ \\
\hline & pilchard & thoracic & LOD-2.954 & LOD-0.006 & $0.010-0.898$ \\
\hline & $\operatorname{cod}$ & total inhalable & ND & ND & $3.800-5.100$ \\
\hline & salmon & total inhalable & ND & ND & LOD-1.600 \\
\hline & herring & total inhalable & ND & ND & $0.300-1.900$ \\
\hline & fishmeal (anchovy) & thoracic & LOD-11.293 & LOD-0.004 & $0.069-75.748$ \\
\hline & shark cartilage & $\begin{array}{l}\text { Respirable } \\
\text { total inhalable }\end{array}$ & $\begin{array}{l}0.920-5.140 \\
26.400-44.700\end{array}$ & $\begin{array}{l}\text { ND } \\
\text { ND }\end{array}$ & $\begin{array}{l}\text { ND } \\
\text { ND }\end{array}$ \\
\hline
\end{tabular}

ND: Not done, LOD: Limit of detection,

* processing aboard vessels; and

** non-food-handling environment

Table 3. Exposure assessment studies of seafood processing workers on land and aboard vessels (Reproduced with permission from (Jeebhay \& Cartier, 2010)

seafood processing workers in the seafood industry(Lopata \& Jeebhay, 2007). Monitoring workplaces will contribute therefore towards engineering controls aimed at improving the ventilation and machine designs, which ultimately will decrease the incidence of asthma associated with seafood exposures.

\section{References}

Aas, K. \& Elsayed, S. (1969). Characterization of a major allergen (cod): Effect of enzymic hydrolysis on the allergenic activity, Journal of Allergy 44(6): 333-343.

Aas, K. \& Elsayed, S. (1975). Physico-chemical properties and specific activity of a purified allergen (codfish), Developments in biological standardization 29: 90-98.

Aas, K. \& Lundkvist, U. (1973). The radioallergosorbent test with a purified allergen from codfish, Clinical \& Experimental Allergy 3(3): 255-261.

Abdel Rahman, A., Gagne, S. \& Helleur, R. (2012). Simultaneous determination of two major snow crab aeroallergens in processing plants by use of isotopic dilution tandem mass spectrometry, Anal. Bioanal. Chem (In press)DOI: http://dx.doi.org/10.1007/s00216-012-5873-2 
Abdel Rahman, A., Kamath, S., Lopata, A. \& Helleur, R. (2010a). Analysis of the allergenic proteins in black tiger prawn (penaeus monodon) and characterization of the major allergen tropomyosin using mass spectrometry, Rapid communications in mass spectrometry 24(16): 2462-2470.

Abdel Rahman, A., Kamath, S., Lopata, A., Robinson, J. \& Helleur, R. (2011). Biomolecular characterization of allergenic proteins in snow crab (chionoecetes opilio) and de novo sequencing of the second allergen arginine kinase using tandem mass spectrometry, Journal of proteomics 74(2): 231-241.

Abdel Rahman, A., Lopata, A., O'Hehir, R., Robinson, J., Banoub, J. \& Helleur, R. (2010b). Characterization and de novo sequencing of snow crab tropomyosin enzymatic peptides by both electrospary ionization and matrix-assisted laser desorption ionization qqtof tandem mass spectrometry, Journal of Mass Spectrometry 45(4): 372-381.

Abdel Rahman, A., Lopata, A., Randell, E. \& Helleur, R. (2010c). Absolute quantification method and validation of airborne snow crab allergen tropomyosin using tandem mass spectrometry, Analytica chimica acta 681(1-2): 49-55.

Aebersold, R. \& Mann, M. (2003). Mass spectrometry-based proteomics, Nature 422(6928): 198-207.

Asturias, J., Eraso, E., Arilla, M., Gómez-Bayón, N., Inácio, F. \& Martínez, A. (2000). Cloning, isolation, and ige-binding properties of helix aspersa (brown garden snail) tropomyosin, International archives of allergy and immunology 128(2): 90-96.

Aukrust, L., Grimmer, O. \& Aas, K. (1978). Demonstration of distinct allergens by means of immunological methods, International Archives of Allergy and Immunology 57(2): 183-192.

Ayuso, R., Grishina, G., Bardina, L., Carrillo, T., Blanco, C., Ibáñez, M., Sampson, H. \& Beyer, K. (2008). Myosin light chain is a novel shrimp allergen, lit v 3, Journal of Allergy and Clinical Immunology 122(4): 795-802.

Ayuso, R., Grishina, G., Ibáñez, M., Blanco, C., Carrillo, T., Bencharitiwong, R., Sánchez, S., Nowak-Wegrzyn, A. \& Sampson, H. (2009). Sarcoplasmic calcium-binding protein is an ef-hand-type protein identified as a new shrimp allergen, Journal of Allergy and Clinical Immunology 124(1): 114-120.

Ayuso, R., Sánchez-Garcia, S., Lin, J., Fu, Z., Ibáñez, M., Carrillo, T., Blanco, C., Goldis, M., Bardina, L., Sastre, J. et al. (2010). Greater epitope recognition of shrimp allergens by children than by adults suggests that shrimp sensitization decreases with age, Journal of Allergy and Clinical Immunology 125(6): 1286-1293.

Azofra, J. \& Lombardero, M. (2003). Limpet anaphylaxis: cross-reactivity between limpet and house-dust mite dermatophagoides pteronyssinus, Allergy 58(2): 146-149.

Bang, B., Aasmoe, L., Aamodt, B., Aardal, L., Andorsen, G., Bolle, R., Bøe, R., Van, T., Evans, R., Florvåg, E. et al. (2005). Exposure and airway effects of seafood industry workers in northern norway, Journal of occupational and environmental medicine 47(5): 482.

Beale, J., Jeebhay, M. \& Lopata, A. (2009). Characterisation of purified parvalbumin from five fish species and nucleotide sequencing of this major allergen from pacific pilchard, sardinops sagax, Molecular immunology 46(15): 2985-2993.

Beaudet, N., Brodkin, C., Stover, B., Daroowalla, F., Flack, J. \& Doherty, D. (2002). Crab allergen exposures aboard five crab-processing vessels, Aiha Journal 63(5): 605-609. 
Besler, M., Eigenmann, P. \& Schwartz, R. (2000). Allergen data collection: Cow's milk (bos domesticus), Internet Symposium on Food Allergens, Publisher, conference location, pp. 9-74.

Besler, M., Steinhart, H. \& Paschke, A. (2001). Stability of food allergens and allergenicity of processed foods, Journal of Chromatography B: Biomedical Sciences and Applications 756(1-2): 207-228.

Bi, X. \& Chew, F. (2004). Molecular, proteomic and immunological characterization of isoforms of arginine kinase, a cross-reactive invertebrate pan-allergen, from the house dust mite, dermatophagoides farinae, Journal of Allergy and Clinical Immunology 113(2): S226-S226.

Binder, M., Mahler, V., Hayek, B., Sperr, W., Schöller, M., Prozell, S., Wiedermann, G., Valent, P., Valenta, R. \& Duchêne, M. (2001). Molecular and immunological characterization of arginine kinase from the indianmeal moth, plodia interpunctella, a novel cross-reactive invertebrate pan-allergen, The Journal of Immunology 167(9): 5470.

Bobolea, I., Barranco, P., Pastor-Vargas, C., Iraola, V., Vivanco, F. \& Quirce, S. (2010). Arginine kinase from the cellar spider (holocnemus pluchei): A new asthma-causing allergen, International Archives of Allergy and Immunology 155(2): 180-186.

Brun, V., Masselon, C., Garin, J. \& Dupuis, A. (2009). Isotope dilution strategies for absolute quantitative proteomics, Journal of proteomics 72(5): 740-749.

Bugajska-Schretter, A., Grote, M., Vangelista, L., Valent, P., Sperr, W., Rumpold, H., Pastore, A., Reichelt, R., Valenta, R. \& Spitzauer, S. (2000). Purification, biochemical, and immunological characterisation of a major food allergen: different immunoglobulin e recognition of the apo-and calcium-bound forms of carp parvalbumin, Gut 46(5): 661.

Cai, Q., Liu, G., Li, T., Hara, K., Wang, X., Su, W. \& Cao, M. (2010). Purification and characterization of parvalbumins, the major allergens in red stingray (dasyatis akajei), Journal of agricultural and food chemistry 58(24): 12964-12969.

Carrera, M., Canas, B., Vazquez, J. \& Gallardo, J. (2010). Extensive de novo sequencing of new parvalbumin isoforms using a novel combination of bottom-up proteomics, accurate molecular mass measurement by fticr-ms and selected $\mathrm{ms} / \mathrm{ms}$ ion monitoring, Journal of Proteome Research 9(9): 4393-4406.

Chait, B. (2004). Chemistry: Mass spectrometry: Bottom-up or top-down?, Neuroscience 123: 931.

Chen, L., Hefle, S., Taylor, S., Swoboda, I. \& Goodman, R. (2006). Detecting fish parvalbumin with commercial mouse monoclonal anti-frog parvalbumin igg, Journal of agricultural and food chemistry 54(15): 5577-5582.

Daul, C., Morgan, J., Hughes, J. \& Lehrer, S. (1988). Provocation-challenge studies in shrimp-sensitive individuals, Journal of allergy and clinical immunology 81(6): 1180-1186.

Daul, C., Slattery, M., Reese, G. \& Lehrer, S. (1994). Identification of the major brown shrimp (penaeus aztecus) allergen as the muscle protein tropomyosin, International archives of allergy and immunology 105(1): 49-55.

Dearnaley, D., Kote-Jarai, Z. \& Eeles, R. (2010). Dietary fat and early-onset prostate cancer risk, British Journal of Nutrition 103(9): 1375-1380.

DeHoffmann, E. \& Stroobant, V. (2007). Mass spectrometry: principles and applications, Wiley-Interscience. 
Desiderio, D. \& Kai, M. (1983). Preparation of stable isotope-incorporated peptide internal standards for field desorption mass spectrometry quantification of peptides in biologic tissue, Biological Mass Spectrometry 10(8): 471-479.

DeWitt, Å., Mattsson, L., Lauer, I., Reese, G. \& Lidholm, J. (2004). Recombinant tropomyosin from penaeus aztecus (rpen a 1) for measurement of specific immuno-globulin e antibodies relevant in food allergy to crustaceans and other invertebrates, Molecular nutrition $\mathcal{E}$ food research $48(5)$ : 370-379.

Do, T. V., Hordvik, I., Endresen, C. \& Elsayed, S. (1999). Expression and analysis of recombinant salmon parvalbumin, the major allergen in atlantic salmon (salmo salar), Scandinavian Journal of Immunology 50(6): 619-625.

Eidhammer, I., Flikka, K., Martens, L. \& Mikalsen, S. (2007). Computational methods for mass spectrometry proteomics, Wiley Online Library.

Elsayed, S. \& Aas, K. (1970). Characterization of a major allergen (cod). chemical composition and immunological properties, International Archives of Allergy and Immunology 38(5): 536-548.

Escudero, R., Gamboa, P., Anton, J. \& Sanz, M. (2007). Food allergy due to trout roe., Journal of investigational allergology \& clinical immunology: official organ of the International Association of Asthmology (INTERASMA) and Sociedad Latinoamericana de Alergia e Inmunología 17(5): 346.

Faeste, C. \& Plassen, C. (2008). Quantitative sandwich elisa for the determination of fish in foods, Journal of immunological methods 329(1-2): 45-55.

Faeste, C., Ronning, H., Christians, U. \& Granum, P. (2011). Liquid chromatography and mass spectrometry in food allergen detection, Journal of Food Protection 74(2): 316-345.

Food and Drug Administration, U. (2001). Guidance for industry: bioanalytical method validation, Rockville, $M D$ : CDER .

Findlay, J., Geisow \& Michael, J. (1989). Protein Sequencing, Practical Approach Series, Oxford University Press.

Food and Agriculture Organisation (FAO) (2007). The state of world fisheries and aquaculture. URL: http://www.fao.org/docrep/013/i1820e/i1820e00.htm, accessed on 30 March 2011

Food and Agriculture Organisation (FAO) (2010). The state of world fisheries and aquaculture. URL: http://www.fao.org/docrep/013/i1820e/i1820e00.htm, accessed on 30 March 2011

France, R., Sellers, D. \& Grossman, S. (1997). Purification, characterization, and hydrodynamic properties of arginine kinase from gulf shrimp (penaeus aztecus)* 1 , Archives of biochemistry and biophysics 345(1): 73-78.

Gajewski, K. \& Hsieh, Y. (2009). Monoclonal antibody specific to a major fish allergen: parvalbumin, Journal of Food Protection 72(4): 818-825.

García-Orozco, K., Aispuro-Hernández, E., Yepiz-Plascencia, G., Calderón-de-la Barca, A. \& Sotelo-Mundo, R. (2007). Molecular characterization of arginine kinase, an allergen from the shrimp (litopenaeus vannamei), International archives of allergy and immunology 144(1): 23-28.

Garone, L., Theibert, J., Miegel, A., Maeda, Y., Murphy, C. \& Collins, J. (1991). Lobster troponin c: amino acid sequences of three isoforms, Archives of biochemistry and biophysics 291(1): 89-91.

Gimenez-Arnau, A., Maurer, M., De La Cuadra, J. \& Maibach, H. (2008). Immediate contact skin reactions, an update of contact urticaria, contact urticaria syndrome and protein contact dermatitis-"a never ending story", European Journal of Dermatology 1(1). 
Greenberg, M. I., Hamilton, R. J. andPhillips, S. D. \& McCluskey, G. J. (2003). Occupational, industrial, and environmental toxocology, Mosby.

Gupta, R., Sheikh, A., Strachan, D. \& Anderson, H. (2007). Time trends in allergic disorders in the uk, Thorax 62(1): 91-96.

Habsah, M., Amran, M., Mackeen, M., Lajis, N., Kikuzaki, H., Nakatani, N., Rahman, A. et al. (2000). Screening of zingiberaceae extracts for antimicrobial and antioxidant activities, Journal of ethnopharmacology 72(3): 403-410.

Halmepuro, L., Salvaggio, J. \& Lehrer, S. (1987). Crawfish and lobster allergens: identification and structural similarities with other crustacea, International Archives of Allergy and Immunology 84(2): 165-172.

Hamada, Y., Nagashima, Y. \& Shiomi, K. (2004). Reactivity of serum immunoglobulin e to bullfrog rana catesbeiana parvalbumins in fish-allergic patients, Fisheries Science 70(6): 1137-1143.

Hoffman, D., Day Jr, E. \& Miller, J. (1981). The major heat stable allergen of shrimp., Annals of allergy 47(1): 17.

Howse, D., Gautrin, D., Neis, B., Cartier, A., Horth-Susin, L., Jong, M. \& Swanson, M. (2006). Gender and snow crab occupational asthma in newfoundland and labrador, canada, Environmental research 101(2): 163-174.

Huang, Y., Liu, G., Cai, Q., Weng, W., Maleki, S., Su, W. \& Cao, M. (2010). Stability of major allergen tropomyosin and other food proteins of mud crab (scylla serrata) by in vitro gastrointestinal digestion, Food and Chemical Toxicology 48(5): 1196-1201.

Hungerford, J. (2006). Committee on natural toxins and food allergens: Marine and freshwater toxins, Journal of AOAC International 89(1): 248-269.

Hungerford, J. \& Trucksess, M. (2005). Committee on natural toxins and food allergens: Marine and freshwater toxins: Mycotoxins, Journal of AOAC International 88(1): 299-324.

Ishikawa, M., Ishida, M., Shimakura, K., Nagashima, Y. \& Shiomi, K. (1998a). Purification and ige-binding epitopes of a major allergen in the gastropod turbo cornutus, Bioscience, biotechnology, and biochemistry 62(7): 1337-1343.

Ishikawa, M., Ishida, M., Shimakura, K., Nagashima, Y. \& Shiomi, K. (1998b). Tropomyosin, the major oyster crassostrea gigas allergen and its ige-binding epitopes, Journal of food science 63(1): 44-47.

James, J. \& Crespo, J. (2007). Allergic reactions to foods by inhalation, Current allergy and asthma reports 7(3): 167-174.

Jauregui-Adell, J., Wnuk, W. \& Cox, J. (1989). Complete amino acid sequence of the sarcoplasmic calcium-binding protein (scp-i) from crayfish (astacus leptodactilus), FEBS letters 243(2): 209-212.

Jeebhay, M. \& Cartier, A. (2010). Seafood workers and respiratory disease: an update, Current opinion in allergy and clinical immunology 10(2): 104-113.

Jeebhay, M., Robins, T., Lehrer, S. \& Lopata, A. (2001). Occupational seafood allergy: a review, Occupational and environmental medicine 58(9): 553-562.

Jeebhay, M., Robins, T., Miller, M., Bateman, E., Smuts, M., Baatjies, R. \& Lopata, A. (2008). Occupational allergy and asthma among salt water fish processing workers, American journal of industrial medicine 51(12): 899-910.

Jeebhay, M., Robins, T., Seixas, N., Baatjies, R., George, D., Rusford, E., Lehrer, S. \& Lopata, A. (2005). Environmental exposure characterization of fish processing workers, Annals of Occupational Hygiene 49(5): 423-437. 
Jenkins, J., Breiteneder, H. \& Mills, E. (2007). Evolutionary distance from human homologs reflects allergenicity of animal food proteins, Journal of Allergy and Clinical Immunology 120(6): 1399-1405.

Jeoung, B., Reese, G., Hauck, P., Oliver, J., Daul, C. B. \& Lehrer, S. (1997). Quantification of the major brown shrimp allergen pen a 1 (tropomyosin) by a monoclonal antibody-based sandwich elisa, Journal of allergy and clinical immunology 100(2): 229-234.

Juji, F., Takashima, H., Suko, M., Doi, M., Takaishi, T., Okudaira, H., Ito, K. \& Miyamoto, T. (1990). A case of food-dependent-exercise induced anaphylaxis possibly induced by shellfish (sulculus supertexta and turbo cornutus), Arerugīi=[Allergy] 39(11): 1515-1522.

Kelleher, N., Lin, H., Valaskovic, G., Aaserud, D., Fridriksson, E. \& McLafferty, F. (1999). Top down versus bottom up protein characterization by tandem high-resolution mass spectrometry, Journal of the American Chemical Society 121(4): 806-812.

Kinter, M. \& Sherman, N. (2000). Protein sequencing and identification using tandem mass spectrometry, LibreDigital.

Kobayashi, T., Takagi, T., Konishi, K. \& Cox, J. (1989). Amino acid sequence of crayfish troponin i, Journal of Biological Chemistry 264(3): 1551-1557.

Koshte, V., Kagen, S. \& Aalberse, R. (1989). Cross-reactivity of ige antibodies to caddis fly with arthropoda and mollusca, Journal of Allergy and Clinical Immunology 84(2): 174-183.

Koyama, H., Kakami, M., Kawamura, M., Tokuda, R., Kondo, Y., Tsuge, I., Yamada, K., Yasuda, T. \& Urisu, A. (2006). Grades of 43 fish species in japan based on ige-binding activity, Allergology International 55: 311-316.

Kuehn, A., Scheuermann, T., Hilger, C. \& Hentges, F. (2010). Important variations in parvalbumin content in common fish species: A factor possibly contributing to variable allergenicity, International archives of allergy and immunology 153(4): 359-366.

Kunimoto, A., Sisino, T., Sakai, K., Matsumoto, T., Takahashi, K., Yamashita, H., Hiemori, M., Tsuji, H. \& Kimoto, M. (2009). Molecular cloning and allergenicity of pen j 1, a major allergen of kuruma prawn, penaeus japonicus, Bioscience, biotechnology, and biochemistry 73(4): 840-848.

Lehky, P., Blum, H., Stein, E. \& Fischer, E. (1974). Isolation and characterization of parvalbumins from the skeletal muscle of higher vertebrates, Journal of Biological Chemistry 249(13): 4332-4334.

Lehrer, S., Horner, W., Reese, G. \& Taylor, S. (1996). Why are some proteins allergenic? implications for biotechnology, Critical reviews in food science and nutrition 36(6): 553-564.

Lehrer, S. \& McCants, M. (1987). Reactivity of ige antibodies with crustacea and oyster allergens: evidence for common antigenic structures, The Journal of allergy and clinical immunology 80(2): 133-139.

Lehrer, S., McCants, M. \& Salvaggio, J. (1985). Identification of crustacea allergens by crossed radioimmunoelectrophoresis, International Archives of Allergy and Immunology 77(1-2): 192-194.

Leung, P., Chow, W., Duffey, S., Kwan, H., Gershwin, M. \& Chu, K. (1996). Ige reactivity against a cross-reactive allergen in crustacea and mollusca: evidence for tropomyosin as the common allergen, Journal of allergy and clinical immunology 98(5): 954-961.

Leung, P. \& Chu, K. (1998). Molecular and immunological characterization of shellfish allergens, Front Biosci 3: 306-312. 
Leung, P., Chu, K., Chow, W. \& andC.I. Bandea, A. A. (1994). Cloning, expression, and primary structure of metapenaeus ensis tropomyosin, the major heat-stable shrimp allergen, Journal of allergy and clinical immunology 94(5): 882-890.

Liang, Y., Cao, M., Su, W., Zhang, L., Huang, Y. \& Liu, G. (2008). Identification and characterisation of the major allergen of chinese mitten crab (eriocheir sinensis), Food Chemistry 111(4): 998-1003.

Lim, D., Neo, K., Yi, F., Chua, K., Goh, D., Shek, L., Giam, Y., Bever, H. V. \& Lee, B. (2008). Parvalbumin-the major tropical fish allergen, Pediatric Allergy and Immunology 19(5): 399-407.

Lin, R., Shen, H. \& Han, S. (1993). Identification and characterization of a $30 \mathrm{kd}$ major allergen from parapenaeus fissurus, Journal of allergy and clinical immunology 92(6): 837-845.

Liu, G., Cao, M., Huang, Y., Cai, Q., Weng, W. \& Su, W. (2010). Comparative study of in vitro digestibility of major allergen tropomyosin and other food proteins of chinese mitten crab (eriocheir sinensis), Journal of the Science of Food and Agriculture 90(10): 1614-1620.

Liu, G., Huang, Y., Cai, Q., Weng, W., Su, W. \& Cao, M. (2011). Comparative study of in vitro digestibility of major allergen, tropomyosin and other proteins between grass prawn (penaeus monodon) and pacific white shrimp (litopenaeus vannamei), Journal of the Science of Food and Agriculture 91(1): 163-170.

Liu, Z., Xia, L., Wu, Y., Xia, Q., Chen, J. \& Roux, K. (2009). Identification and characterization of an arginine kinase as a major allergen from silkworm (bombyx mori) larvae, International archives of allergy and immunology 150(1): 8-14.

Lopata, A. \& Jeebhay, M. (2001). Seafood allergy in south africa studies in the domestic and occupational setting, Allergy and Clinical Immunology International 13(5): 204-209.

Lopata, A. \& Jeebhay, M. (2007). Allergy and asthma to indigenous seafood species in south africa, Current Allergy \& Clinical Immunology 20(4): 197-200.

Lopata, A., Jeebhay, M., Reese, G., Fernandes, J., Swoboda, I., Robins, T. \& Lehrer, S. (2005). Detection of fish antigens aerosolized during fish processing using newly developed immunoassays, International archives of allergy and immunology 138(1): 21-28.

Lopata, A. \& Lehrer, S. (2009). New insights into seafood allergy, Current opinion in allergy and clinical immunology 9(3): 270-277.

Lopata, A., O'Hehir, R. \& Lehrer, S. (2010). Shellfish allergy, Clinical E Experimental Allergy 40(6): 850-858.

Lopata, A., Zinn, C. \& Potter, P. (1997). Characteristics of hypersensitivity reactions and identification of a unique $49 \mathrm{kd}$ ige-binding protein (hal-m-1) in abalone (haliotis midae), Journal of allergy and clinical immunology 100(5): 642-648.

Ma, Y., Griesmeier, U., Susani, M., Radauer, C., Briza, P., Erler, A., Bublin, M., Alessandri, S., Himly, M., Vázquez-Cortés, S. et al. (2008). Comparison of natural and recombinant forms of the major fish allergen parvalbumin from cod and carp, Allergenic and physico-chemical properties of parvalbumins 52(Suppl 2): S196-207.

Mabe, D., Singh, T., Bello, B., Jeebhay, M., Lopata, A. \& Wadee, A. (2009). Allergenicity of latex rubber products used in south african dental schools, SAMJ: South African Medical Journal 99(9): 672-674.

Maeda, S., Morikawa, A., Kato, M., Motegi, Y., Shigeta, M., Tokuyama, K., Kuroume, T., Naritomi, Y., Suehiro, K. \& Kusaba, K. (1991). 11 cases of anaphylaxis caused by grand keyhole limpet (abalone like shellfish), Arerugī=[Allergy] 40(11): 1415.

Malo, J. \& Cartier, A. (1993). Occupational reactions in the seafood industry, Clinical Reviews in Allergy and Immunology 11(2): 223-240. 
Malo, J., Chretien, P., McCants, M. \& Lehrer, S. (1997). Detection of snow-crab antigens by air sampling of a snow-crab production plant, Clinical $\mathcal{E}$ Experimental Allergy 27(1): 75-78.

Marko-Varga, G., Lindberg, H., Löfdahl, C., Jönsson, P., Hansson, L., Dahlbäck, M., Lindquist, E., Johansson, L., Foster, M. \& Fehniger, T. (2005). Discovery of biomarker candidates within disease by protein profiling: principles and concepts, Journal of proteome research 4(4): 1200-1212.

Martins, L., Peltre, G., da Costa Faro, C., Vieira Pires, E. \& da Cruz Inácio, F. (2004). The helix aspersa (brown garden snail) allergen repertoire, International archives of allergy and immunology 136(1): 7-15.

Mazzeo, M., Giulio, B., Guerriero, G., Ciarcia, G., Malorni, A., Russo, G. \& Siciliano, R. (2008). Fish authentication by maldi-tof mass spectrometry, Journal of agricultural and food chemistry 56(23): 11071-11076.

Misnan, R., Murad, S., Jones, M., Taylor, G., Rahman, D., Arip, M., Abdullah, N. \& Mohamed, J. (2010). Identification of the major allergens of indian scad (decapterus russelli), Asian Pacific Journal of Allergy and Immunology 26(4): 191-198.

Miyazawa, H., Fukamachi, H., Inagaki, Y., Reese, G., Daul, C., Lehrer, S., Inouye, S. \& Sakaguchi, M. (1996). Identification of the first major allergen of a squid (todarodes pacificus), Journal of allergy and clinical immunology 98(5): 948-953.

Morgan, J., O'Neil, C., Daul, C. \& Lehrer, S. (1989). Species-specific shrimp allergens: Rast and rast-inhibition studies, Journal of allergy and clinical immunology 83(6): 1112-1117.

Motoyama, K., Suma, Y., Ishizaki, S., Nagashima, Y., Lu, Y., Ushio, H. \& Shiomi, K. (2008). Identification of tropomyosins as major allergens in antarctic krill and mantis shrimp and their amino acid sequence characteristics, Marine Biotechnology 10(6): 709-718.

Motoyama, K., Suma, Y., Ishizaki, S., Nagashima, Y. \& Shiomi, K. (2007). Molecular cloning of tropomyosins identified as allergens in six species of crustaceans, Journal of agricultural and food chemistry 55(3): 985-991.

Mykles, D., Cotton, J., Taniguchi, H., Sano, K. \& Maeda, Y. (1998). Cloning of tropomyosins from lobster (homarus americanus) striated muscles: fast and slow isoforms may be generated from the same transcript, Journal of muscle research and cell motility 19(2): 105-115.

Nagano, T., Kanao, K. \& Sugai, T. (1984). Allergic contact urticaria caused by raw prawns and shrimps: three cases, Journal of allergy and clinical immunology 74(4): 489-493.

Nakamura, R., Satoh, R., Nakajima, Y., Kawasaki, N., Yamaguchi, T., Sawada, J., Nagoya, H. \& Teshima, R. (2009). Comparative study of gh-transgenic and non-transgenic amago salmon (oncorhynchus masou ishikawae) allergenicity and proteomic analysis of amago salmon allergens, Regulatory Toxicology and Pharmacology 55(3): 300-308.

Nakano, S., Yoshinuma, T. \& Yamada, T. (2007). Reactivity of shrimp allergy-related ige antibodies to krill tropomyosin, International archives of allergy and immunology 145(3): 175-181.

Nordlee, J. \& S.L.Taylor (1995). Immunological analysis of food allergens and other food proteins, Food technology (USA) .

Old, W., Meyer-Arendt, K., Aveline-Wolf, L., Pierce, K., Mendoza, A., Sevinsky, J., Resing, K. \& Ahn, N. (2005). Comparison of label-free methods for quantifying human proteins by shotgun proteomics, Molecular E Cellular Proteomics 4(10): 1487.

ONeil, C., Helbling, A. \& Lehrer, S. (1993). Allergic reactions to fish, Clinical Reviews in Allergy and Immunology 11(2): 183-200. 
Oyelaran, O. \& Gildersleeve, J. (2010). Evaluation of human antibody responses to keyhole limpet hemocyanin on a carbohydrate microarray, PROTEOMICS-Clinical Applications 4(3): 285-294.

Pascual, C., Esteban, M. \& Crespo, J. (1992). Fish allergy: evaluation of the importance of cross-reactivity, The Journal of pediatrics 121(5): S29-S34.

Perez-Gordo, M., Cuesta-Herranz, J., Maroto, A., Cases, B., Ibáñez, M., Vivanco, F. \& Pastor-Vargas, C. (2011). Identification of sole parvalbumin as a major allergen: study of cross-reactivity between parvalbumins in a spanish fish-allergic population, Clinical \& Experimental Allergy 41(5): 750-758.

Perez-Gordo, M., Sanchez-Garcia, S., Cases, B., Pastor, C., Vivanco, F. \& Cuesta-Herranz, J. (2008). Identification of vitellogenin as an allergen in beluga caviar allergy, Allergy 63(4): 479-480.

Permyakov, S., Karnoup, A., Bakunts, A. \& Permyakov, E. (2009). Sequence microheterogeneity of parvalbumin pi 5.0 of pike: A mass spectrometric study, Biochimica et Biophysica Acta (BBA)-Proteins \& Proteomics 1794(1): 129-136.

Rabilloud, T. (2000). Proteome research: two-dimensional gel electrophoresis and identification methods, Springer verlag.

Reese, G., Jeoung, B., Daul, C. \& Lehrer, S. (1997). Characterization of recombinant shrimp allergen pen a 1 (tropomyosin), International archives of allergy and immunology 113(1-3): 240-242.

Rehbein, H. \& Lopata, A. (2011). Presence of parvalbumin in different tissues of three sturgeon species (acipenser baeri, a. gueldenstaedtii, a. ruthenus), Journal of Applied Ichthyology 27(2): 219-225.

Reid, G. \& McLuckey, S. (2002). 'top-down' protein characterization via tandem mass spectrometry, Journal of mass spectrometry 37(7): 663-675.

Rejeb, S. B., Davies, D., Cleroux, C., Langlois, D. \& Delahaut, P. (2002). Enzyme immunoassay for the detection of crustacean proteins in foods, Publisher, conference location, p. 102.

Rodriguez, J., Reano, M., Vives, R., Canto, G., Daroca, P., Crespo, J., Vila, C., Villarreal, O. \& Bensabat, Z. (1997). Occupational asthma caused by fish inhalation, Allergy 52(8): 866-869.

Rosmilah, M., Shahnaz, M., Masita, A., Noormalin, A. \& Jamaludin, M. (2005). Identification of major allergens of two species of local snappers: Lutjanus argentimaculatus (merah/red snapper) and lutjanus johnii (jenahak/golden snapper), Trop Biomed 22(2): 171-177.

Sakaguchi, M., Toda, M., Ebihara, T., Irie, S., Hori, H., Imai, A., Yanagida, M., Miyazawa, H., Ohsuna, H., Ikezawa, Z. et al. (2000). Ige antibody to fish gelatin (type i collagen) in patients with fish allergy, Journal of allergy and clinical immunology 106(3): 579-584.

Scherperel, G. \& Reid, G. (2007). Emerging methods in proteomics: top-down protein characterization by multistage tandem mass spectrometry, Analyst 132(6): 500-506.

Schulze, W. \& Usadel, B. (2010). Quantitation in mass-spectrometry-based proteomics, Annual review of plant biology 61: 491-516.

Seiki, K., Oda, H., Yoshioka, H., Sakai, S., Urisu, A., Akiyama, H. \& Ohno, Y. (2007). A reliable and sensitive immunoassay for the determination of crustacean protein in processed foods, Journal of agricultural and food chemistry 55(23): 9345-9350. 
Shanti, K., Martin, B., Nagpal, S., Metcalfe, D. \& Rao, P. (1993). Identification of tropomyosin as the major shrimp allergen and characterization of its ige-binding epitopes, The Journal of Immunology 151(10): 5354.

Shen, Y., Cao, M., Cai, Q., Su, W., Yu, H., Ruan, W. \& Liu, G. (2011). Purification, cloning, expression and immunological analysis of scylla serrata arginine kinase, the crab allergen, Journal of the Science of Food and Agriculture 91(7): 1326-1335.

Shibahara, Y., Yamada, I., Uesaka, Y., Uneo, N., Abe, A., Ohashi, E. \& Shiomi, K. (2009). Extraction method suitable for detection of unheated crustaceans including cephalothorax by elisa., Shokuhin Eiseigaku Zasshi= Journal of the Food Hygienic Society of Japan 50(4): 153-159.

Shiomi, K., Sato, Y., Hamamoto, S., Mita, H. \& Shimakura, K. (2008). Sarcoplasmic calcium-binding protein: Identification as a new allergen of the black tiger shrimp (penaeus monodon), International archives of allergy and immunology 146(2): 91-98.

Sicherer, S., Muñoz-Furlong, A. \& Sampson, H. (2004). Prevalence of seafood allergy in the united states determined by a random telephone survey, Journal of allergy and clinical immunology 114(1): 159-165.

Siuti, N. \& Kelleher, N. (2007). Decoding protein modifications using top-down mass spectrometry, Nature methods 4(10): 817-821.

Suma, Y., Ishizaki, S., Nagashima, Y., Lu, Y., Ushio, H. \& Shiomi, K. (2007). Comparative analysis of barnacle tropomyosin: divergence from decapod tropomyosins and role as a potential allergen, Comparative Biochemistry and Physiology Part B: Biochemistry and Molecular Biology 147(2): 230-236.

Suzuki, M., Kobayashi, Y., Hiraki, Y., Nakata, H. \& Shiomi, K. (2010). Paramyosin of the disk abalone haliotis discus discus: identification as a new allergen and cross-reactivity with tropomyosin, Food Chemistry 124(3): 921-926.

Swoboda, I., Bugajska-Schretter, A., Verdino, P., Keller, W., Sperr, W., Valent, P., Valenta, R. \& Spitzauer, S. (2002). Recombinant carp parvalbumin, the major cross-reactive fish allergen: a tool for diagnosis and therapy of fish allergy, The Journal of Immunology 168(9): 4576-4584.

Taylor, A., Swanson, M., Jones, R., Vives, R., Rodriguez, J., Yunginger, J. \& Crespo, J. (2000). Detection and quantitation of raw fish aeroallergens from an open-air fish market, Journal of allergy and clinical immunology 105(1): 166-169.

Taylor, S. (2008). Molluscan shellfish allergy, Advances in Food and Nutrition Research 54: 139-177.

Taylor, S., Hefle, S., Bindslev-Jensen, C., Bock, S., Jr, A. B., Christie, L., Hill, D., Host, A., Hourihane, J., Lack, G. et al. (2002). Factors affecting the determination of threshold doses for allergenic foods: How much is too much?, Journal of Allergy and Clinical Immunology 109(1): 24-30.

Taylor, S., Kabourek, J. \& Hefle, S. (2004). Fish allergy: fish and products thereof, Journal of food science 69(8): R175-R180.

Towbin, H., Staehelin, T. \& Gordon, J. (1979). Electrophoretic transfer of proteins from polyacrylamide gels to nitrocellulose sheets: procedure and some applications, Proceedings of the National Academy of Sciences 76(9): 4350-4354.

Towle, D. \& Smith, C. (2006). Gene discovery in carcinus maenas and homarus americanus via expressed sequence tags, Integrative and Comparative Biology 46(6): 912-918. 
Van der Ventel, M., Nieuwenhuizen, N., Kirstein, F., Hikuam, C., Jeebhay, M., Swoboda, I., Brombacher, F. \& Lopata, A. (2010). Differential responses to natural and recombinant allergens in a murine model of fish allergy, Molecular Immunology 48(4): 637-646.

Weber, P., Steinhart, H. \& Paschke, A. (2009). Competitive indirect elisa for the determination of parvalbumins from various fish species in food grade fish gelatins and isinglass with parv-19 anti-parvalbumin antibodies, Journal of agricultural and food chemistry 57(23): 11328-11334.

Weber, P., Steinhart, H. \& Paschke, A. (2010). Characterization, antigenicity and detection of fish gelatine and isinglass used as processing aids in wines, Food Additives $\mathcal{E}$ Contaminants: Part A 27(3): 273-282.

Werner, M., Fæste, C. \& Egaas, E. (2007). Quantitative sandwich elisa for the determination of tropomyosin from crustaceans in foods, Journal of agricultural and food chemistry 55(20): 8025-8032.

Werr, M., Cramer, J. \& Ilg, T. (2009). Identification and characterization of two arginine kinases from the parasitic insect ctenocephalides felis, Insect biochemistry and molecular biology 39(9): 634-645.

Weytjens, K., Cartier, A., Malo, J., Chretien, P., Essiembre, F., Lehrer, S. \& Swanson, M. (1999). Aerosolized snow-crab allergens in a processing facility, Allergy 54(8): 892-893.

White, A., Northcutt, M., Rohrback, S., Carpenter, R., Niehaus-Sauter, M., Gao, Y., Wheatly, M. \& Gillen, C. (2011). Characterization of sarcoplasmic calcium binding protein (scp) variants from freshwater crayfish procambarus clarkii, Comparative Biochemistry and Physiology Part B: Biochemistry and Molecular Biology . in press.

Wild, L. \& Lehrer, S. (2005). Fish and shellfish allergy, Current Allergy and Asthma Reports 5(1): 74-79.

Yamasaki, A., Higaki, H., Nakashima, K., Yamamoto, O., Hein, K., Takahashi, H., Chinuki, Y. \& Morita, E. (2010). Identification of a major yolk protein as an allergen in sea urchin roe, Acta dermato-venereologica 90(3): 235-238.

Yao, C., Wu, C., Xiang, J. \& Dong, B. (2005). Molecular cloning and response to laminarin stimulation of arginine kinase in haemolymph in chinese shrimp, fenneropenaeus chinensis, Fish $\mathcal{E}$ shellfish immunology 19(4): 317-329.

Yoon, S., Kim, H., Kim, H., Choi, J., Suh, C., Nahm, D., Kim, Y., Min, K. \& Park, H. (2004). Identification of the major allergen in the shrimp (metapenaeus joyneri): Effects of heating and digestive enzymes, Korean Journal of Asthma, Allergy and Clinical Immunology 24(2): 211-216.

Yu, C., Lin, Y., Chiang, B. \& Chow, L. (2003). Proteomics and immunological analysis of a novel shrimp allergen, pen $\mathrm{m}$ 2, The Journal of Immunology 170(1): 445-453.

Yu, H., Cao, M., Cai, Q., Weng, W., Su, W. \& Liu, G. (2010). Effects of different processing methods on digestibility of scylla paramamosain allergen (tropomyosin), Food and Chemical Toxicology 49(4): 791-798.

Zhang, Y., Matsuo, H. \& Morita, E. (2006). Cross-reactivity among shrimp, crab and scallops in a patient with a seafood allergy, The Journal of dermatology 33(3): 174-177.

Zhang, Z. \& McElvain, J. (2000). De novo peptide sequencing by two-dimensional fragment correlation mass spectrometry, Analytical chemistry 72(11): 2337-2350. 


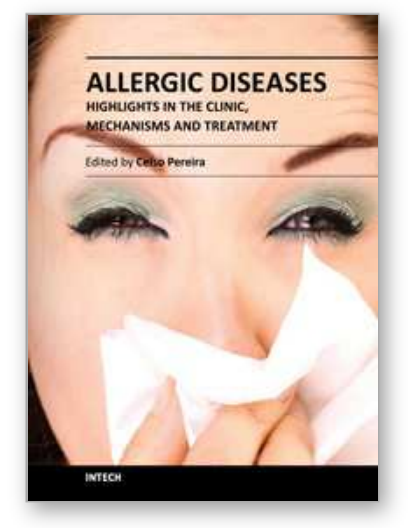

\author{
Allergic Diseases - Highlights in the Clinic, Mechanisms and \\ Treatment \\ Edited by Prof. Celso Pereira
}

ISBN 978-953-51-0227-4

Hard cover, 554 pages

Publisher InTech

Published online 14, March, 2012

Published in print edition March, 2012

The present Edition "Allergic diseases - highlights in the clinic, mechanisms and treatment" aims to present some recent aspects related to one of the most prevalent daily clinical expression disease. The effort of a group of outstanding experts from many countries reflects a set of scientific studies very promising for a better clinical care and also to the treatment and control of the allergy. This book provides a valuable reference text in several topics of the clinical allergy and basic issues related to the immune system response. The inflammatory reaction understanding in allergic disease is clearly evidenced, as well as new strategies for further researches.

\title{
How to reference
}

In order to correctly reference this scholarly work, feel free to copy and paste the following:

Anas M. Abdel Rahman, Robert J. Helleur, Mohamed F. Jeebhay and Andreas L. Lopata (2012).

Characterization of Seafood Proteins Causing Allergic Diseases, Allergic Diseases - Highlights in the Clinic, Mechanisms and Treatment, Prof. Celso Pereira (Ed.), ISBN: 978-953-51-0227-4, InTech, Available from: http://www.intechopen.com/books/allergic-diseases-highlights-in-the-clinic-mechanisms-andtreatment/characterization-of-seafood-proteins-causing-allergic-diseases

\section{INTECH}

open science | open minds

\section{InTech Europe}

University Campus STeP Ri

Slavka Krautzeka 83/A

51000 Rijeka, Croatia

Phone: +385 (51) 770447

Fax: +385 (51) 686166

www.intechopen.com

\section{InTech China}

Unit 405, Office Block, Hotel Equatorial Shanghai

No.65, Yan An Road (West), Shanghai, 200040, China

中国上海市延安西路65号上海国际贵都大饭店办公楼 405 单元

Phone: +86-21-62489820

Fax: +86-21-62489821 
(C) 2012 The Author(s). Licensee IntechOpen. This is an open access article distributed under the terms of the Creative Commons Attribution 3.0 License, which permits unrestricted use, distribution, and reproduction in any medium, provided the original work is properly cited. 